\title{
Nitric Oxide (NO) and NO Synthases (NOS)-Based Targeted Therapy for Colon Cancer
}

\author{
Hao Wang ${ }^{1,+}$, Liye Wang ${ }^{2,+}$, Zuoxu Xie ${ }^{2}$, Shuang Zhou ${ }^{2}$, Yan $\mathrm{Li}^{2}$, Yue Zhou ${ }^{3}$ \\ and Meiyan Sun $1, *$ (D) \\ 1 College of Laboratory Medicine, Jilin Medical University, Jilin 132013, China; 87115wh@163.com \\ 2 Department of Pharmacological and Pharmaceutical Science, College of Pharmacy, University of Houston, \\ Houston, TX, 77204, USA; lwang53@uh.edu (L.W.); zxie3@Central.UH.EDU (Z.X.); \\ goldenshuang1929@gmail.com (S.Z.); yli97@uh.edu (Y.L.) \\ 3 Department of Statistics, North Dakota University, Fargo, ND 58105, USA; yue.zhou@ndsu.edu \\ * Correspondence: sunmy990@163.com \\ + These authors contributed equally to this work.
}

Received: 30 May 2020; Accepted: 10 July 2020; Published: 13 July 2020

\begin{abstract}
Colorectal cancer (CRC) is one of the most lethal malignancies worldwide and CRC therapy remains unsatisfactory. In recent decades, nitric oxide (NO) - a free-radical gas-plus its endogenous producer NO synthases (NOS), have attracted considerable attention. NO exerts dual effects (pro- and anti-tumor) in cancers. Endogenous levels of NO promote colon neoplasms, whereas exogenously sustained doses lead to cytotoxic functions. Importantly, NO has been implicated as an essential mediator in many signaling pathways in CRC, such as the Wnt/ $\beta$-catenin and extracellular-signal-regulated kinase (ERK) pathways, which are closely associated with cancer initiation, metastasis, inflammation, and chemo-/radio-resistance. Therefore, NO/NOS have been proposed as promising targets in the regulation of CRC carcinogenesis. Clinically relevant NO-donating agents have been developed for CRC therapy to deliver a high level of NO to tumor sites. Notably, inducible NOS (iNOS) is ubiquitously over-expressed in inflammatory-associated colon cancer. The development of iNOS inhibitors contributes to targeted therapies for CRC with clinical benefits. In this review, we summarize the multifaceted mechanisms of NO-mediated networks in several hallmarks of CRC. We review the clinical manifestation and limitations of NO donors and NOS inhibitors in clinical trials. We also discuss the possible directions of NO/NOS therapies in the immediate future.
\end{abstract}

Keywords: nitric oxide; NO; NO synthases; NOS; iNOS; targeted therapy; chemoprevention; NO delivery system; colon cancer; clinical manifestation; clinical implication

\section{Introduction}

Colorectal cancer (CRC) is the third most commonly diagnosed malignancy worldwide [1]. Epidemiology models estimate that there will be 104,610 new cases and 53,200 deaths in the U.S. among males and females in 2020 [2]. Surgery and chemotherapies are the most common strategies employed for CRC treatment. However, clinical outcomes suggest a poor five-year survival rate $(<10 \%)$ in patients with advanced CRC due to distant metastasis, recurrence, chemo-/radio-resistance, and multiple drug resistance (MDR) [3,4]. Advances in understanding colon carcinogenesis, drug discovery, and drug delivery systems contribute to novel targeting strategies for CRC prevention and therapy [5].

Nitric oxide (NO) can be synthesized in mammalian cells [6]. In various tissues, this free-radical gas is endogenously generated from L-arginine by a family of enzymes named NO synthases (NOSs), including neuronal NOS (nNOS/NOS1), inducible NOS (iNOS/NOS2), and endothelial NOS 
(eNOS/NOS3) [7-11]. Among these, eNOS and nNOS are found in endothelial cells and neuronal cells, respectively. Intriguingly, eNOS and nNOS are constitutive, calcium-dependent isoforms with a low-output of NO, whereas inducible NOS (iNOS) is a calcium-independent and constantly inducible isoform. Therefore, iNOS can produce a high (nM) level of NO for an extended period. Additionally, iNOS is a macrophage-type enzyme which can be stimulated by oxidative stress, pro-inflammatory signals, and inflammatory cytokines [12,13]. NO and NOSs are involved in a plethora of physiological pathways. However, NO responses are context-dependent and highly dependent on the levels of NO. In this review, we provide an overview of the role of NO/NOSs in the hallmarks of cancer, particularly in CRC. We also discuss the conventional and innovative paradigms of NO donors and NOS chemo-inhibitors for CRC prevention and therapy.

\section{Paradox Criteria of NO in Cancers}

NO has a biphasic effect on cancer development [14]. The response to the action of NO is concentration-dependent [15]. Low levels of $\mathrm{NO}$ are prone to favor cell growth and anti-apoptotic responses, whereas high levels of NO are likely to induce cell cycle arrest and apoptosis $[6,16]$. Experiments have shown that particular signaling pathways are activated/inhibited when endothelial cells are exposed to different concentrations of NO [17-20]. Cyclic guanosine monophosphate (cGMP) signaling can be activated at the lowest doses of $\mathrm{NO}$, inducing the proliferation of human endothelial cancer cells. The cGMP pathway acts as a critical player, mediating either the acute response to NO (5 $\min$ to $1 \mathrm{~h}$ ) or the long-term proliferation response [21]. As NO doses increase, PI3 kinase-Akt signaling can be directly activated by $\mathrm{NO}$, which is associated with migration and angiogenesis in endothelial cells [22]. However, at higher local concentrations $(>1 \mu \mathrm{m})$, NO stabilizes the hypoxia-inducible factors (HIF-1 $\alpha$ ), which is linked with suppressed cell proliferation and delayed wound repair [23]. Moreover, when the cells are exposed to a substantial amount of NO, the growth will be hindered due to the accumulation of p53 [24]. Indeed, accumulated p53 is found in human cells when exposed to high levels of NO, which is produced by a NO donor or by the overexpression of iNOS. An increase in iNOS expression and p53 mutations are also found at the inflamed colon sites of patients with ulcerative colitis (UC) [25].

Consistently, studies have reported that, in breast cancer cells (MCF7 cells), signaling proteins respond to various amounts of NO. Extracellular-signal-regulated kinase (ERK) is phosphorylated at the NO level of 10-30 nM, and Akt is phosphorylated at 30-60 nM NO. When NO reaches $100 \mathrm{nM}$, HIF- $1 \alpha$ is stabilized. Around $400 \mathrm{nM}$, such a high output of NO initiates the phosphorylation of p53 [15].

Interestingly, a previous study has indicated that NO supports tumor growth and mediates tumor vascularization at an early stage but may oppose such actions at advanced stages with metastasis. This is consistent with the finding that the expression of iNOS reduces with the advance of tumor stages and is low or undetectable in metastasis to the lung and liver $[26,27]$.

\section{Biphasic Role of NO in Cancers}

In the role of NO in cancer tumorigenesis, the low levels of NO generated by NOS lead to tumor initiation and progression by several mechanisms: (i) NO induces DNA damage; (ii) NO interferes with DNA repair; (iii) NO activates oncogenes; (iv) NO decreases apoptosis; (v) NO causes post-translational modification; and (vi) NO causes gene mutations under chronic and malignant conditions, such as the accumulation of mutant p53. Besides, NO participates in cancer-associated signaling pathways, including Wnt, Ras, ERK, Akt, cyclin D1, mammalian target of rapamycin (mTOR), and retinoblastoma $(\mathrm{Rb})$ pathways. NO also mediates the events of angiogenesis, epithelial-mesenchymal transition (EMT), and metastasis [15,28-33]. It has been reported that NO increases Matrix Metallopeptidase-2 and -9 (MMP-2)/MMP-9 and activated ERK-1/2 and activating protein 1 (AP-1) in colon adenocarcinoma cells in a time-dependent manner [34]. 
NO exogenously provided by NO donors participates in cytotoxicity effects against colorectal cancer with the following mechanisms: (i) NO inhibits DNA synthesis; (ii) NO inhibits angiogenesis; (iii) NO inhibits EMT; (iv) NO reduces mutations of p53; (v) NO deactivates Cyclooxygenase-2 (COX-2); (vi) NO activates caspase family proteases; (vii) NO alters the expression of apoptosis-associated proteins, such as the Bcl-2 family; and (viii) NO decreases p21. One study revealed that NO was involved in CRC carcinogenesis in a p53-dependent manner. This demonstrated that p53-dependent miRNAs were associated with the resistance of CRC cells to NO-induced apoptosis. The upregulation of these miRNAs sensitized the NO-induced apoptotic death in HT-29 cells [35].

In recognition of the anti-tumor effects of NO, NO-donating agents, and delivery systems are being developed to manipulate NO levels in the tumor environment [12,36-41].

\section{Role of NOS in Colon Carcinogenesis}

\section{1. $n N O S / N O S 1$}

Previous studies have demonstrated that NOS1 promotes the survival of nasopharyngeal carcinoma cells and cancer-associated fibroblasts, but little has been related to colon cancer [42,43]. A recent study suggested that mitochondrial NOS1 ( $\mathrm{mtNOS1}$ ) is involved in chemotherapeutic resistance in colon cancer cells via inducing SIRT3 activity. This finding also indicates that NOS1-induced apoptotic resistance in CRC can be overcame by inhibitors targeting NOS1 [44].

\section{2. $i N O S / N O S 2$}

In the last few decades, iNOS has been at the center of attention in terms of its role in human colonic tumorigenesis. It has been reported that iNOS is highly expressed in almost $60 \%$ of human colon adenomas, whereas it is low or undetectable in normal intestinal tissues $[27,45]$. Interestingly, the expression level of iNOS attenuated in an advanced tumor with metastasis, and was absent in human mesenchymal CRC subtypes [46].

Epidemiologic research has demonstrated that inflammatory bowel disease is closely correlated with CRC [47]. iNOS was frequently detected at inflammatory sites, both in patients with ulcerative colitis (UC) and colonic neoplasms. This suggested that iNOS-induced NO levels might be higher in inflammatory and tumor tissues than in normal tissues [48,49]. Indeed, higher expression levels of iNOS were found in both human colitis and carcinoma tissues than in non-carcinoma tissues [50-53]. The presence of a high iNOS level has been found in human CRC cell HT-29 under an inflammatory condition [54]. Besides, it is well-known that MMP-2 plays a critical role in invasion and metastasis, and is more active in colonic colitis and cancer compared to controls [26]. Studies have shown an increase of iNOS in MMP-2-related invasion and metastasis in colorectal cancer [11,55]. Furthermore, iNOS is involved in the NF-kB pathway [29]. These findings suggest that iNOS might be an indicator of human colon cancer and inflammation at early stages. It is known that iNOS and COX-2 are correlated with a poor prognosis and high biological aggressiveness of tumor cells [56]. One study reported an upregulation of iNOS and COX-2 in colorectal cancer [26]. The product of NO is higher in more advanced disease, thus demonstrating an essential role of iNOS in the development of CRC [9,31].

\section{3. eNOS/NOS3}

As reported in previous studies, the role of eNOS in tumorigenesis is mainly due to its aberrant expression in endothelial cells and tumors $[57,58]$. Indeed, a high expression of eNOS was detected in undifferentiated tumor tissues compared to differentiated tumor tissues in a murine mammary mice model [59]. An upregulation of eNOS was found in rat colon tumors induced by azoxymethane [60]. Recent studies revealed that eNOS might be involved in various tumor hallmarks, including invasion, metastasis, angiogenesis, and resistance [61,62]. Therefore, eNOS could act as a marker for poor prognosis in human cancer $[46,63]$. Peñarando et al. explored the mechanism of eNOS in mesenchymal colorectal cancer and cancer stem cells. They depicted that eNOS was upregulated in human colorectal 
tumor subtypes, including the human mesenchymal CRC subtype. In patients with CRC, eNOS was also enhanced at the initial stage, along with APC loss [60]. Notably, the authors demonstrated that eNOS was highly expressed in different cancer stem cell (CSC) phenotypes, which included different conditional CRC mice models, poorly differentiated adenocarcinomas, and human mesenchymal CMS tumors. This finding identified eNOS as a possible novel biomarker in poor-prognostic mesenchymal colorectal tumors. Moreover, a new NO scavenger named cPTIO was found, which impaired the stem-related signaling pathways in the CSC phenotypes, and inhibited organoid and tumor formation. Their study suggested eNOS as a promising target in human mesenchymal colorectal tumors [46].

\section{NOS Inhibitors: Targeting NOS in Colon Cancer}

As mentioned above, all of the NOS isoforms play an essential role in the development of colon cancer. Therefore, in the past few years, various NOS inhibitors have been developed [28]. NOS inhibitors have been preclinically determined to reduce the endogenous production of NO, and thus suppress colonic tumor and inflammatory formation [30]. However, due to the constitutive expression and central role of eNOS in smooth muscle relaxation and the control of vascular tone and blood pressure, the inhibition of eNOS may result in unexpected side effects. Moreover, several studies have shown an increase in iNOS expression in human colon adenomas [31]. Therefore, scientists have been making efforts to find selective iNOS inhibitors. In addition, some researchers believe that iNOS-specific inhibitors could be developed as safer and more effective chemo-preventive agents against colon cancer in comparison to COX-2 inhibitors, which may cause renal toxicity [26]. Here, we discuss typical examples of NOS inhibitors, which are classified into two categories: natural extracts and synthesized compounds. The key information—including the targets, mechanism, and inhibited protein—are listed in Table 1. 
Table 1. Paradigms of NO synthases (NOS) chemo-inhibitors for colon cancer treatment

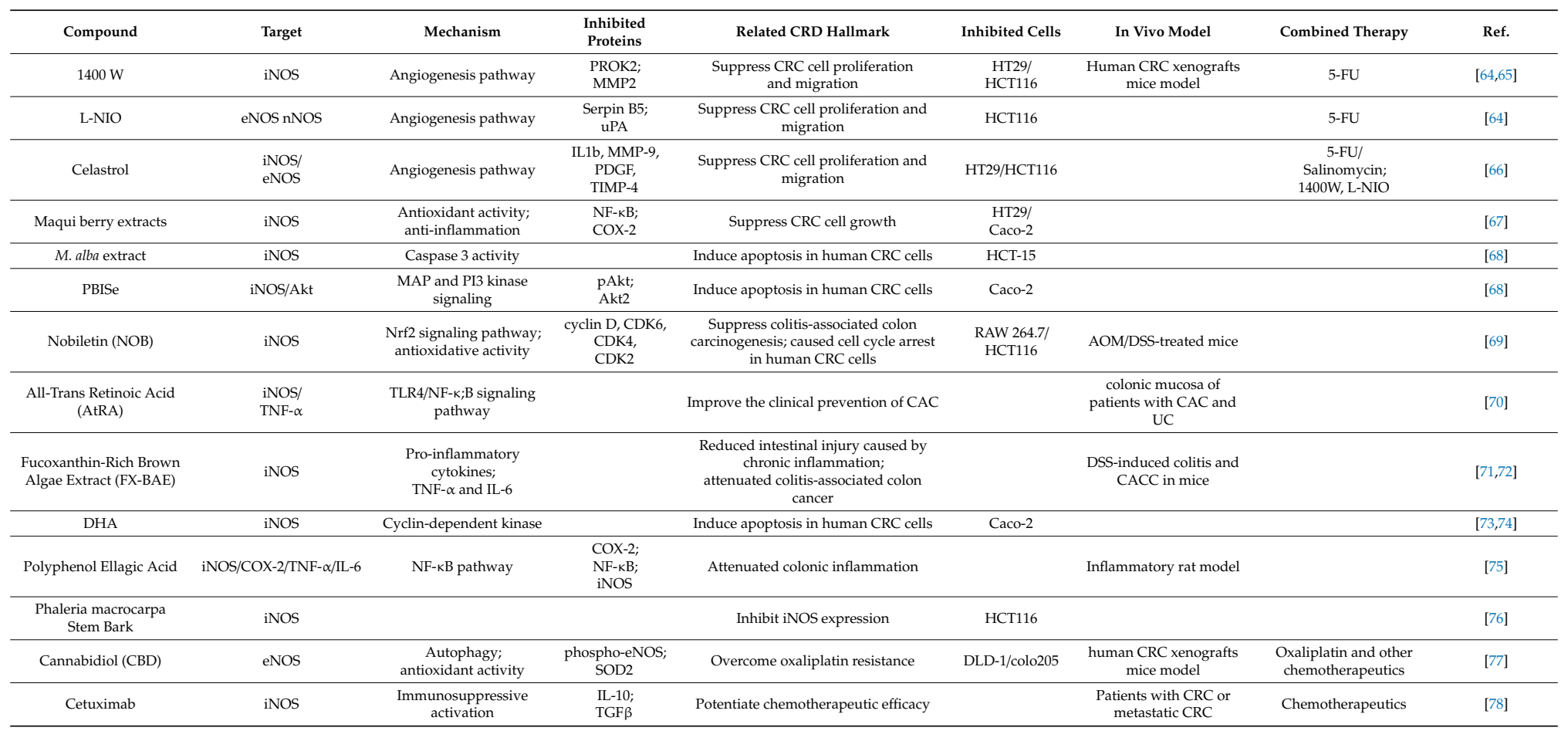




\subsection{NOS Inhibitors from Natural Extracts}

\subsubsection{Celastrol (Tripterine)}

Our recent study [66] demonstrated that celastrol (tripterine), extracted from the thunder god vine, inhibited the activities of iNOS and eNOS in CRC cells. The inhibitory effects in cell growth and migration were associated with the angiogenesis pathway. This was the first study on the combinational use of the NOS inhibitor celastrol with first-line chemotherapy reagents, such as 5-FU, in CRC. It showed synergistic anti-proliferation effects in CRC cells.

\subsubsection{Maqui Berry (MB) Extracts}

It has been reported that Maqui berry (MB) extracts downregulated the expression of iNOS, resulting in the inhibition of NO production in human CRC cells. This study provided evidence that MB extracts potently protect against CRC. Moreover, the extracts showed antioxidant and anti-inflammatory abilities in human CRC cells, as the structural feature of extracts might be associated with the inhibition of NF-kB and COX-2 [67].

\subsubsection{Cannabidiol (CBD)}

Jeong et al. first reported that the combined administration of CBD and oxaliplatin not only inhibited tumor growth, but also induced autophagic death by decreasing phospho-eNOS and SOD2 in oxaliplatin-resistant CRC cells, which suggested that CBD could work as a new therapeutic agent to overcome the chemo-resistance of oxaliplatin in human CRC cells, sparing the neurotoxic side effects of oxaliplatin [77].

\subsubsection{Phaleria Macrocarpa}

A recent study determined the inhibitory effects of an ethanol extract, Phaleria macrocarpa stem bark, on the expression of iNOS in CRC cell line HCT116 [76].

\subsubsection{All-Trans Retinoic Acid (AtRA)}

Rafa et al. suggested that AtRA exerted a clinically preventive effect in patients with ulcerative colitis (UC) and colitis-associated cancer (CAC). Mechanically, AtRA regulated the TLR-4/NF- $\kappa$;B pathway targeting iNOS in colonic mucosa. Moreover, they revealed a correlation with the expression of iNOS and TNF-a in the colonic mucosa. AtRA inhibited the expression of iNOS and TNF-a [70]. This study offered a new strategy in which AtRA could protect against CAC and UC development.

\subsubsection{Dietary Polyphenol Ellagic Acid}

Umesalma et al. reported that ellagic acid suppressed colon cancer in rats. In their subsequent study, they explored the precise mechanism of ellagic acid against colonic inflammation through the NF-KB pathway to reduce the expression of iNOS, TNF-a, and IL-6. Ellagic acid could be regarded as a promising chemo-preventive agent due to its anti-tumor and anti-inflammatory effects [75].

\subsection{Synthesized NOS Inhibitors}

\subsection{1. $1400 \mathrm{~W}$ and L-NIO}

Our recent study [64] confirmed that the blockage of iNOS or eNOS significantly inhibited CRC cell proliferation due to the reduced level of NO. Two NOS inhibitors, $1400 \mathrm{~W}$ and L-NIO, hindered the CRC cell growth and migration. Additionally, we demonstrated that such an inhibitory effect of $1400 \mathrm{~W}$ and L-NIO on CRC cells functions, in part, by suppressing angiogenesis pathway and angiogenesis-related proteins. In addition, this was the first attempt examining the combinational 
use of $1400 \mathrm{~W}$ or L-NIO with the chemotherapy drug 5-FU, and successfully presented a synergistic anti-proliferation effect in CRC cells.

\subsubsection{Se,Se'-1,4-Phenylenebis(1,2-Ethanediyl)Bis-Isoselenourea (PBISe)}

PBISe, a newly synthesized iNOS inhibitor, has been suggested as a potent agent for attenuating CRC cell proliferation, but inducing apoptosis. It significantly inhibited iNOS, PI3 kinase, and pAkt signaling in CRC cells. Notably, this study elucidated that upon exposure to PBISe, a decrease in the levels of pAkt and Akt2 and an increase in p27 were found in CRC cells [71]. Taken together, PBISe could be considered a novel selenium compound inhibiting CRC cell growth, while its inhibitory effects in animal models are currently under investigation.

5.2.3. S,S9-1,4-Phenylene-Bis(1,2-Ethanediyl)Bis-Isothiourea (PBIT)/L-N6-(1-Iminoethyl)Lysinetetrazole-Amide (SC-51)

PBIT is an iNOS inhibitor. It has been reported that PBIT modulated iNOS and COX activities against aberrant crypt foci (ACF) in the colon of rats and colonic mucosa. Interestingly, PBIT selectively and competitively inhibited the levels of iNOS compared with eNOS or nNOS. It provided data showing that an NOS-specific inhibitor might be safer than COX-2 inhibitors, which may cause renal toxicity [26].

Another study found that the selective iNOS inhibitors L-N6-(1-iminoethyl)lysine tetrazole-amide (SC-51) and aminoguanidine (AG) selectively suppressed iNOS against colonic ACF formation. Notably, the co-administration of celecoxib, a COX-2 inhibitor, and SC-51 or AG exerted a more potent inhibition on iNOS against colonic ACF formation than when the agents were administrated individually [68]. This finding demonstrated that the combinational use of iNOS inhibitors and COX-2 inhibitors might have additional potential in CRC chemo-prevention.

\subsection{NOS Inhibitors from Nutraceuticals}

\subsubsection{Nobiletin and Its Colonic Metabolites (NOB-Met)}

Wu et al. orally administrated NOB and its major metabolites as a mixture (NOB-Met) to CRC cells. They found that NOB-Met inhibited iNOS expression in colitis-associated colon cancer. Moreover, NOB-Met inhibited cell proliferation by increasing p27 and p53 and decreasing cyclin D, CDK2, CDK4, and CDK6 in CRC cells. This was the first study demonstrated that NOB-Met exerts anti-tumor and anti-inflammation effects in CRC via downregulating iNOS and upregulating antioxidative enzymes [69]. This study revealed that NOB-Met could be a good nutraceutical candidate for colonic cancer and inflammation prevention [69].

\subsubsection{Omega-3 Fatty Acid Docosahexaenoic Acid (DHA)}

A previous study reported that DHA could induce CRC cell apoptosis by targeting iNOS and NF- $\mathrm{KB}$. This was the first study showing that DHA modulates CRC cell growth via the inhibition of iNOS and COX-2 [74].

\section{Traditional and Innovative NO Donor-Based Therapy}

NO donor-based therapy is a newly developed strategy for cancer therapy as it (1) achieves more potent anti-tumor effects; (2) overcomes chemo-/radio-resistance; and (3) reduces gastrointestinal toxicity via an enhanced specificity. NO donor-based therapy has been advanced from an NO donor alone towards the (1) co-administration of NO donors with other chemo-/radio-/immune-therapy; (2) hybridization of NO donors with gaseous transmitters, such as hydrogen sulfide $\left(\mathrm{H}_{2} \mathrm{~S}\right)$ and carbon monoxide (CO); (3) combinational use of iNOS and COX inhibitors; and (4) application of drug delivery systems, such as nanotechnology, to deliver a high level of NO to the tumor sites. In this section, 
we review the advances of NO donor-based therapy in CRC made in the past decades and provide prospects [79-83].

\subsection{Nitric-Oxide-Donating Nonsteroidal Anti-Inflammatory Drugs (NO-NSAIDs) in Cancers}

In 1973, Lawrence Levine first suggested that NSAIDs had an anti-tumor effect in fibrosarcoma-bearing mice [84]. In the 1980s, considerable data generated by preclinical studies, clinical investigations, and epidemiological work revealed that NSAIDs could prevent colon cancer [85-90]. Notably, a clinical study conducted by Waddell and Gerner in patients with familial adenomatous polyposis (FAP), a condition in which a person develops numerous adenomas in the colon and rectum, suggested that NSAIDs may offer a bright clinical insight into CRC protection [91]. However, due to the gastrointestinal (GI) toxicity and risk associated with NSAIDs, celecoxib, the NSAID used for FAP in clinics was withdrawn by the FDA [92,93]. Safer alternatives need to be developed [87]. NO-donating NSAIDs (NO-NSAIDs) possess a traditional NSAID moiety and an NO-donating moiety, which are covalently coupled by a spacer molecule [94]. NO-NSAIDs share the anti-cancer and pharmacological properties with their parent NSAIDs [95]. Impressively, the application of an NO-donating moiety to an NSAID might carry NO to tumor sites and compensate for the reduction of gastric prostaglandin (PG), largely contributing to the diminished gastric toxicity and mucosal injury $[87,96]$. To the best of our knowledge, there is no safer alternative for patients with FAP. We believe that NO-NASIDs might be a promising candidate. Moreover, we believe that the development of NO-NASIDs could rekindle researchers' interests in FAP and CRC therapy. Herein, we list some in vitro, in vivo preclinical, and clinical examples of NO donors with different chemical properties for colon cancer therapy (Tables 2 and 3). 
Table 2. Paradigms of NO donors for colon cancer treatment

\begin{tabular}{|c|c|c|c|c|c|c|}
\hline NO Donor & Properties & Mechanism & Chemo-Preventative Effects & Inhibited Cells & In Vivo Model & Ref. \\
\hline NO-NSAIDs & & & $\begin{array}{l}\text { Suppress CRC cell proliferation; block } \\
\text { cell cycle transition }\end{array}$ & HT-29 & & [95] \\
\hline $\begin{array}{l}\text { NO-aspirin } \\
\text { (NO-ASA) }\end{array}$ & NO-NSAID & $\begin{array}{c}\text { Induce COX-2; } \\
\text { Inhibit the } \beta \text {-catenin/TCF4 } \\
\text { signaling pathway }\end{array}$ & Inhibit CRC cell growth & HT-29/DLD-1 & & [95] \\
\hline NCX-4016 & $\mathrm{NO}$ aspirin derivate & $\begin{array}{l}\text { Independent of any inhibitory activity } \\
\text { on COX-1 or COX-2 }\end{array}$ & $\begin{array}{l}\text { Reduce aberrant crypt foci (ACF) } \\
\text { in colon }\end{array}$ & & $\begin{array}{c}\text { Azoxymethane } \\
(\mathrm{AOM}) \text {-induced mice }\end{array}$ & [97] \\
\hline $\begin{array}{l}\text { NOSH-aspirin } \\
(\text { NBS-1120) }\end{array}$ & $\begin{array}{l}\text { NO- and } \mathrm{H}_{2} \mathrm{~S} \text {-releasing } \\
\text { NSAID }\end{array}$ & Inhibit cyclo-oxygenase enzyme activity & $\begin{array}{l}\text { Suppress CRC cell proliferation; induce } \\
\text { apoptosis; block cell cycle }\end{array}$ & HT-29 & $\begin{array}{l}\text { Human xenograft } \\
\text { mouse model }\end{array}$ & [98] \\
\hline $\begin{array}{c}\text { NOSH-sulindac } \\
\text { (AVT-18A) }\end{array}$ & $\begin{array}{l}\text { NO- and } \mathrm{H}_{2} \text { S-releasing } \\
\text { NSAID } \\
\end{array}$ & Inhibit COX-1 and COX-2 & $\begin{array}{l}\text { Anti-colon cancer activity and } \\
\text { anti-inflammation }\end{array}$ & HT-29/SW-480/HCT-15 & Rat & [99] \\
\hline $\begin{array}{c}\text { NO donor } \\
\text { Doxorubicin } \\
\text { (NO-DOXOs) }\end{array}$ & & $\begin{array}{l}\text { Inhibit cellular drug efflux; nitration of } \\
\text { tyrosine residues of MRP3 protein }\end{array}$ & $\begin{array}{l}\text { Induce cytotoxicity in } \\
\text { colon cancer cells; }\end{array}$ & $\begin{array}{l}\text { doxorubicin-resistant } \\
\text { HT-29 }\end{array}$ & & [100] \\
\hline $\begin{array}{l}\text { CDDO-Amino Acid-Nitric } \\
\text { Oxide Donor Trihybrids }\end{array}$ & & $\begin{array}{l}\text { Inhibit HIF- } 1 \alpha, \text { ERK, Stat } 3 \text {, and } \\
\text { AKT signaling }\end{array}$ & $\begin{array}{c}\text { Anti-tumor effect against } \\
\text { chemo-sensitive and chemo-resistant } \\
\text { CRC }\end{array}$ & $\begin{array}{c}\text { HCT-8; } \\
\text { HCT-8/5-FU }\end{array}$ & & [101] \\
\hline Glyceryl trinitrate (GTN) & & Activate caspase- 1 and caspase- 10 & $\begin{array}{l}\text { Induce apoptosis in } \\
\text { colon cancer cells }\end{array}$ & HCT116 & In clinics & [102] \\
\hline GT-094 & NO-NASID & $\begin{array}{l}\text { Activate the ROS-miR-27a:ZBTB10-Sp } \\
\text { transcription factor pathway }\end{array}$ & Inhibit CRC cell growth & RKO/SW480 & & [103] \\
\hline
\end{tabular}


Table 3. In vivo paradigms of NOS chemo-inhibitors/NO donors for colon cancer treatment

\begin{tabular}{|c|c|c|c|c|c|}
\hline Compound & In Vivo Model & Mechanism & Treatment (Dose/Duration) & Therapeutic Efficacy & Ref. \\
\hline $1400 \mathrm{~W}$ & $\begin{array}{l}\text { Genetically engineered xenograft mice } \\
\text { model with constitutive iNOS expression } \\
\text { (colon adenocarcinoma DLD-1) }\end{array}$ & Angiogenesis pathway & $6 \mathrm{mg} / \mathrm{kg}-1 / \mathrm{h}-11400 \mathrm{~W} / 13$ days & Inhibited tumor growth & [65] \\
\hline Nobiletin (NOB) & AOM/DSS colon cancer model on CD-1 mice & $\begin{array}{l}\text { iNOS } \downarrow \\
\text { antioxidative enzymes } \uparrow \\
\text { cell cycle } \downarrow\end{array}$ & $\begin{array}{c}\text { AIN93G diet containing NOB ( } 0.05 \mathrm{wt} \% \text { in } \\
\text { diet)/ } \\
1 \text { week after the AOM injection until the end } \\
\text { of study }\end{array}$ & $\begin{array}{l}\text { Suppressed colitis-associated colon } \\
\text { carcinogenesis }\end{array}$ & [69] \\
\hline $\begin{array}{l}\text { All-Trans Retinoic Acid } \\
\text { (AtRA) }\end{array}$ & $\begin{array}{l}\text { Ex vivo; } \\
\text { colonic mucosa of patients with CAC and UC }\end{array}$ & $\begin{array}{c}\text { LPS/TLR4/NF-KB } \\
\text { signaling pathway } \\
\text { NOS2 } \downarrow \\
\text { TNF- } \alpha \downarrow\end{array}$ & $\begin{array}{l}\text { 10-7 M AtRA } / 6 \mathrm{~h} \text {; stimulated with } 10 \mu \mathrm{g} / \mathrm{mL} \\
\text { lipopolysaccharide (LPS) }\end{array}$ & $\begin{array}{l}\text { Clinically prevented the CAC development } \\
\text { and progression }\end{array}$ & [70] \\
\hline $\begin{array}{l}\text { Fucoxanthin-Rich Brown } \\
\text { Algae Extract (FX-BAE) }\end{array}$ & $\begin{array}{l}\text { DSS-induced colitis and CACC model in } \\
\text { BALB/c mice }\end{array}$ & Oxidative stress $\downarrow$ & $\begin{array}{l}\text { Colitis: fed with FX-BAE } 1,2 \text {, or } 5 \mathrm{~g} / \mathrm{kg} / \text { day } \\
\text { from day } 8 \text { to day } 14 ; \text { CACC: fed with } \\
\text { FX-BAE at } 0.5,1 \text {, or } 2.5 \mathrm{~g} / \mathrm{kg} \text { every } 2 \text { days }\end{array}$ & $\begin{array}{l}\text { Decreased the incidence of colonic neoplasm; } \\
\text { increased superoxide dismutase (SOD) } \\
\text { production, lymphocyte proliferation; } \\
\text { prolonged survival rate in CACC mice }\end{array}$ & {$[71,72]$} \\
\hline Polyphenol Ellagic Acid & $\begin{array}{l}\text { 1,2-dimethylhydrazine-induced colon cancer } \\
\text { model on Wistar albino rats }\end{array}$ & $\begin{array}{c}\text { Anti-inflammatory } \\
\text { NF--kB pathway } \downarrow \\
\text { iNOS } \downarrow \\
\text { COX-2 } \downarrow \\
\text { TNF- } \alpha \downarrow \\
\text { IL-6 } \downarrow\end{array}$ & $\begin{array}{l}60 \mathrm{mg} / \mathrm{kg} \text { ellagic acid } / \text { p.o./every day for } \\
15 \text { weeks }\end{array}$ & Chemo-prevention on colon carcinogenesis & [75] \\
\hline Cannabidiol (CBD) & $\begin{array}{l}\text { Colo205 xenograft model on BALB/c nude } \\
\text { mice }\end{array}$ & $\begin{array}{c}\text { CBD overcomes } \\
\text { NOS-induced oxaliplatin } \\
\text { resistance by inducing } \\
\text { autophagy }\end{array}$ & CBD + oxaliplatin (i.p.) & Overcame the resistance to oxaliplatin & [77] \\
\hline Cetuximab & $\begin{array}{c}\text { Ex vivo; } \\
\text { CRC tissue explant culture }\end{array}$ & $\begin{array}{c}\text { iNOS } \downarrow \\
\text { immunosuppressive } \\
\text { cytokines } \uparrow\end{array}$ & Cetuximab + chemotherapy $(\mathrm{CTX}+\mathrm{Chemo})$ & $\begin{array}{l}\text { Potentiated the chemo-therapeutic } \\
\text { efficacy }\end{array}$ & [78] \\
\hline NCX-4016 & TNBS-AMO colon cancer model on rats & $\begin{array}{l}\text { Independent of any } \\
\text { inhibitory activity on } \\
\text { COX-1 or COX-2 } \\
\text { cell proliferation }\end{array}$ & $\begin{array}{l}10 \mathrm{mg} / \mathrm{kg} \mathrm{NCX}-4016 \text { after four- weeks } \\
\text { administration of AOM }\end{array}$ & Reduce aberrant crypt foci (ACF) in colon & [97] \\
\hline $\begin{array}{l}\text { NOSH-aspirin } \\
\text { (NBS-1120) }\end{array}$ & Human colon cancer xenograft model & $\begin{array}{c}\text { apoptosis } \uparrow \\
\text { the blockage of } \mathrm{G}(0) / \mathrm{G}(1) \\
\text { cell cycle }\end{array}$ & & Reduced the tumor volume by $85 \%$ & [98] \\
\hline
\end{tabular}




\subsection{NO-NSAIDs in CRC}

Current data indicates that NO-NSAIDs exert anti-neoplasia effects on colon adenocarcinomas [95]. As has been reported, the anti-tumor effects of NO-NSAIDs are a hundred- to thousand-fold more potent than those of parent NSAIDs [94]. In 1998, Bak et al. first determined that an NO-donating aspirin (NO-ASA) derivative, NCX-4016, exhibited over a 30\% reduction of aberrant crypt foci (ACF) compared to that of aspirin (NO-ASA: 85\% reduction of ACF; aspirin: $64 \%$ reduction of ACF) in a rat model bearing tumors. The result supported the superior chemo-preventive effects of NO-ASA in colon adenocarcinoma [97]. Consistently, Williams et al. found that NO-NSAIDs much more potently inhibited the growth of human colon cancer cell HT-29 than the parental NSAID alone. The IC50 of NO-ASA in HT-29 cells was $10 \mathrm{mM}$ within $72 \mathrm{~h}$, whereas that of aspirin was $2500 \mathrm{mM}$. Ample evidence has demonstrated that NO-ASA is the most potent NO-NSAID in various cancer cell lines [104-109]. Besides, NO-NSAIDs have been regarded as safe agents in clinical studies [110-121]. Evidence also suggests that the phenotypes of NO-NSAIDs-such as NO-ASA, NO-sulindac, and NO-ibuprofen-inhibit human CRC cell proliferation more effectively than parent NO-NSAIDs [122]. $\mathrm{NO}$-ASA has been proven to reach a superior effectiveness, even hundreds- or thousands-fold greater than the other NO-NSAIDs, offering a novel and effective strategy for colon cancer chemo-prevention. Mechanically, research has shown that some signaling pathways are involved in the suppressive effects of NO-ASA in colon carcinogenesis, including the Wnt and NF-kB signaling pathways, NOS, and cyclooxygenase (COX) enzymes [123,124]. For example, NO-ASA hampered the activation of NF-kB by interfering with its translocation into the nucleus [125]. NO-ASA inhibits iNOS expression in CRC cell line HT-29 [126]. Additionally, a reduction of iNOS activities has also been found in NO-ASA-treated F344 rats with azoxymethane-induced colon cancer [127]. Furthermore, a novel NO-NSAID, GT-094, inhibited CRC cell growth, in part, by activating an ROS-miR-27a:ZBTB10-Sp pathway in RKO and SW480 cells [103]. Interestingly, NO-ASA induced COX-2 expression in HT-29 and DLD-1 CRC cell lines, whereas PGE2 was inhibited under the co-administration of NO-ASA and ASA (200 $\mu \mathrm{m}$ NO-ASA; $20 \mu \mathrm{m}$ ASA) [126]. Structurally, three positional isomers of NO-ASA-namely ortho, meta, and para, inhibited $\beta$-catenin and TCF4 signaling (1-4\% of the IC50 for cell growth inhibition)—suggesting the potential of NO-ASA to interfere in prominent signaling pathways in chemoprevention for CRC or other cancers [127].

\subsection{NO- and $\mathrm{H}_{2} \mathrm{~S}$-Releasing NSAIDs in $\mathrm{CRC}$}

NOSH-aspirin (NBS-1120, NOSH-ASA) is a hybrid incorporating two gaseous mediators: NO and $\mathrm{H}_{2} \mathrm{~S}$. A preclinical study showed that $\mathrm{NOSH}$-aspirin inhibited tumor growth in a human colon cancer xenograft mice model [128]. Chattopadhyay et al. first developed this NO- and $\mathrm{H}_{2} \mathrm{~S}-$ releasing NSAID and tested its efficacy on the suppression of colon cancer in vitro and in vivo [98]. Surprisingly, NOSH-aspirin was 9000-fold more potent towards CRC growth inhibition than the sum of its parts, with IC50 in the nano-molar range. Subsequent experiments confirmed the high potency of NOSH-aspirin in growth suppression, apoptosis induction, and cell cycle blockage in CRC cell lines. A recent study provided another NO- and $\mathrm{H}_{2} \mathrm{~S}$-releasing NSAID, NOSH-sulindac (AVT-18A), which conjugated a $\mathrm{NO}$-releasing group and $\mathrm{H}_{2} \mathrm{~S}$-releasing group into the parent compound sulindac. $\mathrm{NOSH}$-sulindac exerts a 1000- to 9000-fold growth inhibition greater than that of sulindac in human CRC cell lines HT-29, SW-480, and HCT-15. It induced apoptosis and blockage of the $\mathrm{G}_{2} / \mathrm{M}$ cell cycle. Preclinical data highlighted its anti-growth events against various human cancer cells without GI toxicity [99].

\subsection{Nitric Oxide Donor Doxorubicin (NO-DOXOs)}

A study conducted by Chegaev et al. designed new DOXO semisynthetic derivatives, namely NO-DOXOs, through conjugating doxorubicin with NO donor nitrooxy and phenylsulfonyl furoxan moieties. Subsequent experiments indicated that NO-DOXOs could accumulate and induce a high 
cytotoxicity in doxorubicin-resistant human colon cancer cells (HT29-dx) [100]. The work provided NO-releasing hybrids as a feasible strategy to address multidrug resistance (MDR) for CRC treatment.

\section{Application and Delivery of Nitric Oxide for Colon Cancer}

Nowadays, there are two foci in studies of NO in drug delivery systems for cancers: (1) augmenting the enhanced permeability and retention (EPR) effect for drug delivery; and (2) facilitating the delivery of NO to tumor sites. In this review, we focus more on the application of NO delivery in colon cancer.

\subsection{Augmented EPR Effects by the NO Drug Delivery System}

In 1986, Yasuhiro Matsumura and Hiroshi Maeda originally proposed the concept of the EPR effect, by which particles or macromolecules of a certain size tend to accumulate in the tumor tissue [129]. Typically, the newly formed tumor has unique pathophysiological characteristics, such as extensive angiogenesis and hypervasculature, defective vascular architecture, and a greatly increased production of a number of permeability mediators. Furthermore, tumor tissues usually lack effective lymphatic drainage [130]. However, due to the heterogeneity of the EPR effect, in some cases, it is difficult to deliver drugs to tumors [131]. Therefore, researchers developed various methods to augment the EPR effect via modulating many factors, such as bradykinin, nitric oxide, prostaglandins, etc. [132-136]. $\mathrm{NO}$, as a major endothelium-dependent vasodilator produced by large blood vessels, can regulate microvascular blood flow and vascular permeability [137]. So far, many preclinical studies have demonstrated that NO can potentiate the EPR effect (Figure 1A). Clinically, an NO donor, glyceryl trinitrate, has been used to enhance the therapeutic efficacy [36].

However, since the vascular networking pattern will influence the tumor blood flow response to the systemic vasodilators, the systemic administration of a non-selective NO-donating substance may not increase - and may even reduce - the tumor blood flow. Waliul Islam et al. [138] exploited the benefit of three NO-donating agents nitroglycerin (NG), hydroxyurea, and L-arginine for the efficacy of nanomedicine by enhancing the EPR effect. After quantifying the amount of NO in tissues at 4 and $24 \mathrm{~h}$ after administration, they found that all three NO-donating agents could selectively increase the amount of NO in tumors. Thereafter, the administration of NO-donating agents could significantly increase (1.5-2 times) the accumulation of polymer-conjugated pirarubicin (P-THP) in the tumor. In the colon cancer C26 model, the combinational use of $5 \mathrm{mg} / \mathrm{kg}$ P-THP and NO-donating agents exerted a similar or better therapeutic effect than that of $15 \mathrm{mg} / \mathrm{kg}$ P-THP only. Moreover, compared to the P-THP alone, in the AOM/DSS-induced autochthonous murine colon cancer model, P-THP combined with NO-donating agents notably reduced both the number and size of polyps in the colon. In another study, Jun Fang et al. [139] used NG to enhance the EPR effect for the delivery of bacteria. After NG treatment, they found that the number of bacteria in tumor tissue had increased around 70-fold, 20-fold, and 10 -fold at 1, 6, and $24 \mathrm{~h}$, respectively. In addition, combined with NG, the bacteria could remarkedly prolong the survival length of rats with colon tumors. 
A

Drug Delivery by EPR Effect

EPR Effect Enhanced by NO

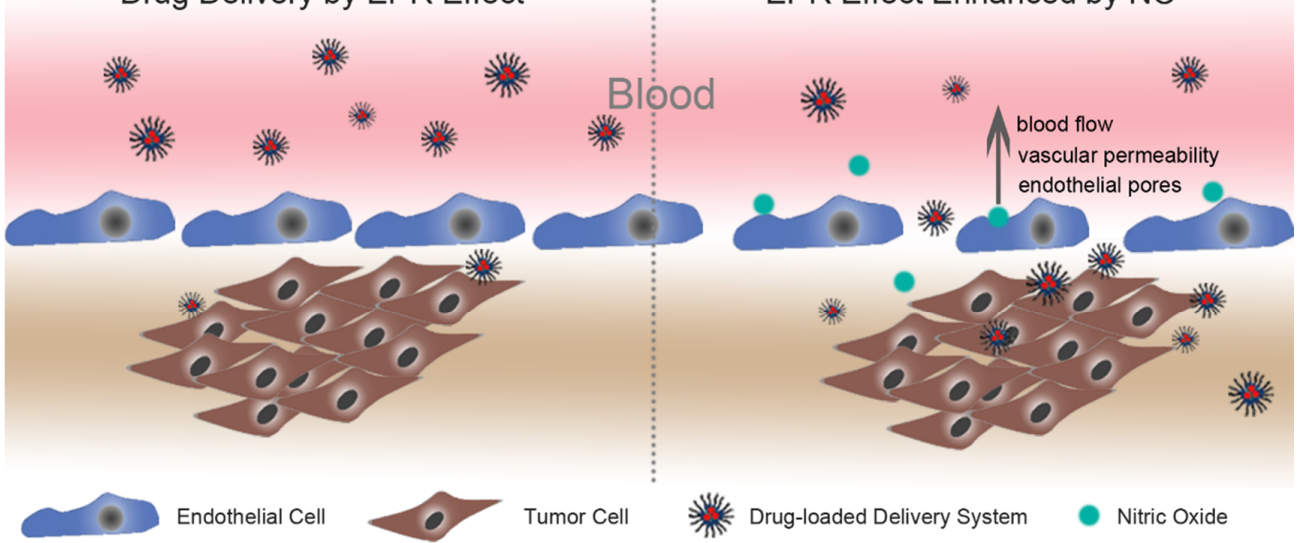

B

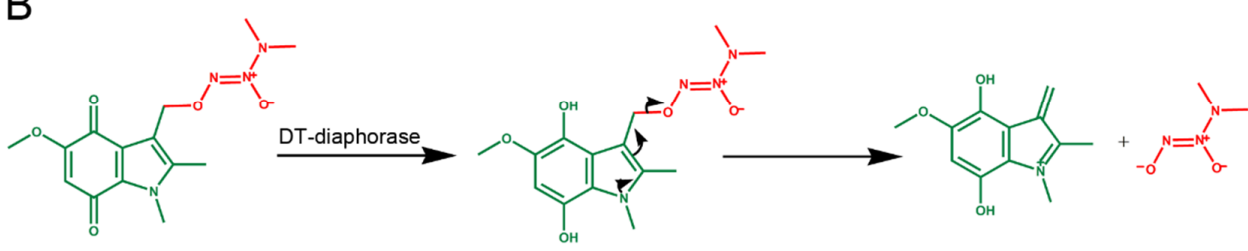

C

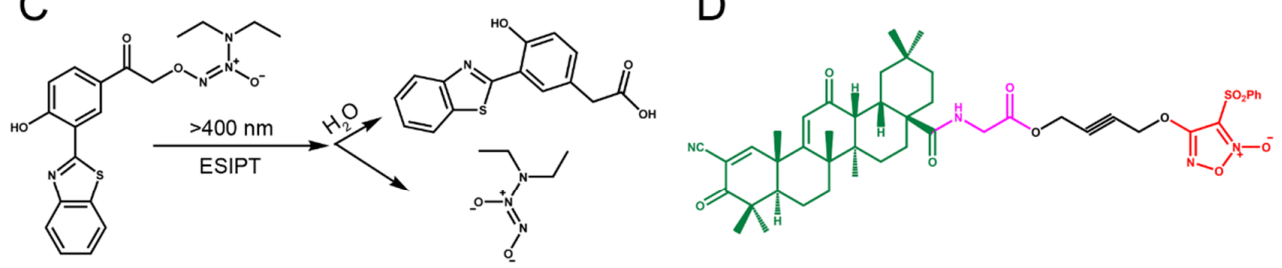

E

Delivery of NO without stimulus

Delivery of NO with stimuli releasing

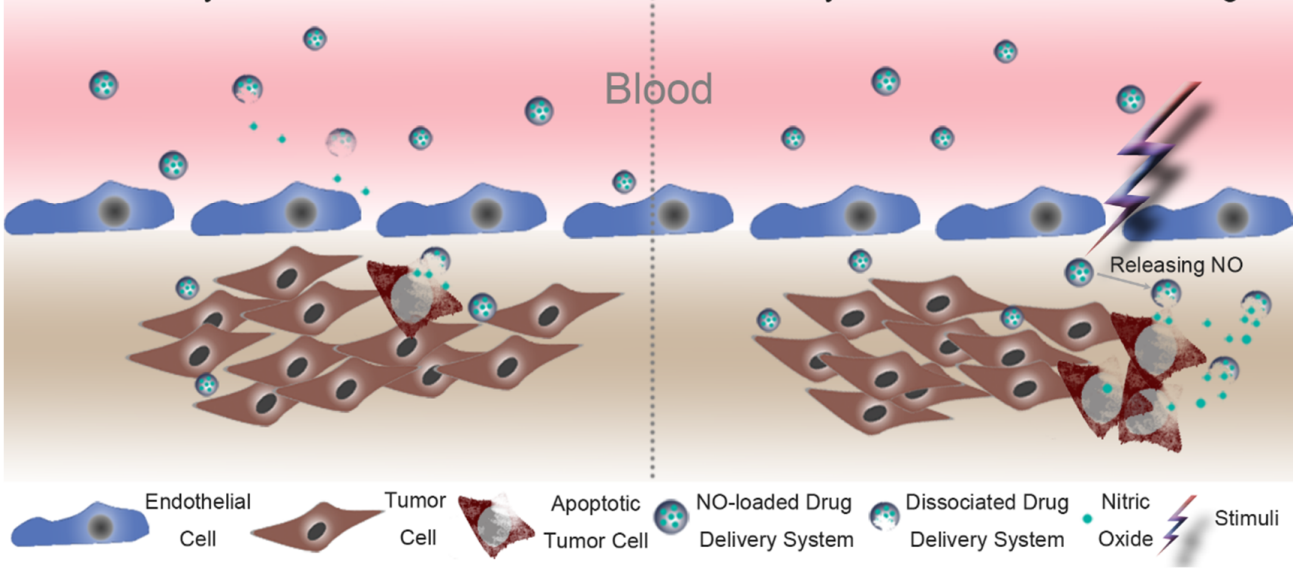

Figure 1. (A) Schematic illustration of the enhanced permeability and retention (EPR) effect by donated nitric oxide (NO). The donated NO can cause the endothelium-dependent relaxation of vascular smooth muscle, which will increase the blood flow and vascular permeability. Under this situation, the endothelial pores which serve as the gateway will be enlarged for particles and drugs; (B) Design of a DT-diaphorase-activated NO-donating agent; (C) Design of a photo-activated NO-donating agent; (D) Design of a transporter-mediated NO-donating agent; (E) Schematic illustration of nano-scaled NO delivery system with or without stimuli. Without stimulus, the NO-loaded delivery system will spontaneously release the NO in the normal tissue or tumor. For the stimuli-responsive delivery system, the release of $\mathrm{NO}$ can be controlled specifically by applying stimuli (e.g., ultrasound and light) at the tumor sites. 


\subsection{Delivery of NO for Targeted Cancer Therapy}

NO-donating agents such as S-nitrosothiols, diazeniumdiolates, and furoxans have been reported to show anti-neoplasia effects in certain cancer cells [140]. However, due to the reactive and unstable nature of these kinds of NO-donating agents, their systemic administration may cause unexpected effects resulting from non-specific activation and targeting. To precisely deliver $\mathrm{NO}$ to tumor sites, small molecules, and nano-scaled molecules or particles which utilize the abnormalities of the tumor microenvironment have been arousing people's interest.

For small molecules, the targeted release of $\mathrm{NO}$ can be achieved by conjugating NO-donating agents to a triggering group, which can respond to the low $\mathrm{pH}$ situation or specifically overexpressed enzymes in the tumor tissue. The newly formed molecules usually exist as an inactive form with less systemic toxicity. An indolequinone-diazeniumdiolate was reported to exhibit the targeting ability once activated by $\mathrm{NAD}(\mathrm{P}) \mathrm{H}$ : quinone oxidoreductase 1 (DT-diaphorase), a bioreductive enzyme that is overexpressed in colon cancer [141]. Induced by DT-diaphorase, the 4,7-dioxoindole indolequinone-diazeniumdiolate was transformed into a 4,7-dihydroxyindole intermediate to liberate the lone pair electron for releasing a diazeniumdiolate anion (Figure 1B). Thereafter, at a physiological $\mathrm{pH}$, the diazeniumdiolate anion will dissociate to generate NO. Another example of diazeniumdiolate employed UV or visible light to selectively release NO in the tumor tissue [142]. In this study, the photochemical NO-donating agent- $\mathrm{O}^{2}$-(3-(benzothiazole-2-yl)-4-hydroxyphenacyl) diazeniumdiolate-could be triggered by visible light and then release NO (Figure 1C). A more potent antitumor activity against the colon cancer cells was observed under visible light than in the dark.

In addition to the enzyme and photo triggering strategy, Yong Ai et al. [101] employed the peptide transporter 1, involved in the transportation of amino acids and peptides, to transport the NO-donating agents to the cancer cells. The authors synthesized CDDO-amino acid-NO donor trihybrids by using the amino acid to link 2-cyano-3,12-dioxooleana-1,9(11)-dien-28-oic acid (CDDO), which is an oleanolic acid derivative with antitumor activity, with the NO-donating agent furoxan (Figure 1D). The CDDO-amino acid-NO donor had more potent antitumor activity against drug-sensitive and drug-resistant colon cancer cells when compared with the compound individually. Moreover, the antitumor effect of this trihybrid has been demonstrated in colon tumor-bearing mice.

Regarding the use of nano-scaled medicines to deliver NO, NO-loaded particles utilize the EPR effect to passively target tumor tissue, followed by releasing NO spontaneously or via endogenous or exogenous stimuli (Figure 1E). The furoxan is not only developed into a tumor-directed NO-donating small molecule, but is also embedded in an amphiphilic block copolymer to form nano-scaled micelles [143]. The furoxan-bearing micelles can respond to the cysteine, which is rich in the cell, to release the $\mathrm{NO}$ and exert an anti-proliferative effect in colon cancer cells.

The human serum albumin (HSA), as a long-acting and safe NO delivery system, has been well-studied. Initially, HSA was used to carry NO by Stamler et al. in 1992 [144]. Although, since then, the nitrosated HSA (NO-HSA) has been investigated for various therapeutic applications, the first study on the effect of NO-HSA on cancer started in 2008 [145]. Masaki Otagiri and Toru Maruyama's team found that NO-HSA could inhibit the proliferation of colon cancer cells in a concentration-dependent manner. Furthermore, the NO-HSA could induce the apoptosis of cancer cells to significantly suppress the tumor growth of colon tumor-bearing mice. However, NO-HSA might not exert its greatest potential because of the poor stability, insufficient circulation time, and suboptimal particle size. To overcome these drawbacks, PEGylation or a resizing strategy has been applied to modulate the NO-releasing rate and targeting capability of NO-HAS [146]. As a result, PEGylated NO-HAS became more stable both in vitro and in vivo, and the dimeric NO-HAS showed more potent antitumor activity against colon cancer. From the results of the in vivo antitumor study, they found that the antitumor activity of the NO-HSA dimer was at least 10 times higher than that of NO-HSA. Sequentially, Masaki Otagiri and Toru Maruyama's team studied the effects of NO-HSA on the EPR effect for nano-scaled drug delivery systems, such as micelles, liposomes, and albumin nanoparticles $[147,148]$. They stated that the improved antitumor effect of the combinative administration of the NO-HSA dimer and nanomedicines 
should be attributed to the enhancement of the EPR effect by the NO-HSA. However, we found that the administration of NO-HSA alone could significantly suppress tumor growth in the results of in vivo antitumor studies. Therefore, the improved antitumor effect of combinative administration may result from the additive or synergistic effects of the NO-HSA dimer and nanomedicines.

More recently, endogenous or exogenous stimuli-such as a low $\mathrm{pH}$, infrared light, and ultrasound-have been used to control NO release after NO-loaded drug delivery systems accumulate in the tumor tissue via the EPR effect. However, compared to the conventional drug delivery system, the increased complexity may limit its clinical application, although the stimuli-response drug delivery system can improve the targeting efficiency. The potential of the stimuli-response drug delivery system for delivering NO has been explored in other cancer models, and has recently been reviewed in detail $[149,150]$. However, few pieces of literature were found reporting the implementation of the stimuli-response drug delivery system for the delivery of NO for CRC treatment.

\section{Clinical Manifestation of NO/NOS in Colon Cancer}

Given the aggressive involvement of NOSs in many signaling pathways related to CRC initiation, NOSs have been considered to be indicators for patients with poor-prognostic colon carcinoma subtypes. Schirripa et al. investigated the feasibility of iNOS as a prognostic marker in mCRC patients; however, they failed to replicate the results [151].

Meanwhile, the efficacy of NOS chemo-inhibitors produced from plants/fruit extracts or daily nutraceuticals targeting specific NOS has been determined in preclinical work. However, few inhibitors have been advanced to clinical investigations. In patients, AtRA successfully exerts a preventive effect on UC and CAC by targeting iNOS [70].

Clinical trials have been conducted to study a commonly used NO donor, glyceryl trinitrate (GTN), which is a drug that was initially used for heart failure in clinics. A phase I trial found that GTN exerted beneficial effects on patients with colon, lung, and prostate cancers [152]. Another phase II trial suggested that GTN could improve the sensibility of patients with advanced lung cancer to chemotherapies [153].

A preclinical study found NO-donating aspirin, acetylsalicyclic acid (NCX-4016), provides protection against aspirin-induced gastric damage. In 2020, a 10-year follow-up study concluded that taking $600 \mathrm{mg}$ aspirin for at least 2 years significantly reduces the incidence of colon cancer in people who are carriers of Lynch syndrome [154]. These findings suggest that NO-donating aspirin might be a good candidate for CRC therapy. A phase I trial studied the best doses and side effects of NCX-4016 in protecting patients at a high risk of CRC $[151,155,156]$. However, the clinical study of NCX-4016 did not move forward to Phase II and III trials for unknown reasons. Additionally, NO donors achieveed unfavorable pharmacokinetics in clinical practice[157]. Continuing efforts are still needed to prove the possibility of positioning NOS inhibitors and NO donors in the clinical arena.

\section{Discussion and Conclusions}

Conventional chemo-therapy generates poor patient outcomes due to the heterogeneity of colon cancer, resulting in chemo-/radio-resistance and MDR [158]. In recent decades, numerous attempts have been made to develop targeted strategies for CRC therapy with clinical benefits. Two decades ago, people started to study the anti-tumor effect of NO-donating agents on colon cancer [159], and proposed NO donor-based therapy as a promising strategy to CRC for clinical purposes. However, the paradoxical properties of $\mathrm{NO}$ are troublesome when manipulating $\mathrm{NO}$ as a potential therapeutic option in different microenvironments, as it may inevitably be associated with both benefits and risks.

NO donor-based therapy mainly includes NO donor single therapy; its combination with anticancer drug(s)/agent(s); and its hybridization with gaseous transmitters, such as $\mathrm{CO}$ or $\mathrm{H}_{2} \mathrm{~S}$. However, the adverse effects of traditional NO donors limit their clinical use, predominantly due to the off-target effects. Moreover, the uncontrolled release of NO has the risk of the rapid bursting of toxic agents, such as nitrates, which always results in acute toxicity in patients. To address the clinical 
limitations, a targeted/controlled delivery system-such as NO-donating nanoparticles-is urgently needed to specifically deliver precise doses at tumor sites to avoid cytotoxic levels in adjacent normal tissues. An imaging system for NO-donating compounds also needs to be developed to monitor and/or capture the compounds in vivo. For example, NO-donating compounds could be coupled with a fluorescent group. Most importantly, the real beneficial effects of newly developed NO donors and delivery systems need to be investigated in animal and clinical trials.

A monoclonal antibody drug is considered to be a novel NO-donating candidate with a high targeting ability and affinity. Recently, a novel antibody-drug conjugate (ADC)-like immunoconjugate-namely, antibody-nitric oxide conjugate (ANC)—drew attention as it could specifically deliver cytotoxins to tumor cells/tissues, giving an emerging missile with higher immunotherapeutic outcomes, but lower toxic effects. The developed anti-CD24 antibody G7mAb, acting as a vehicle, selectively targeted hepatic carcinoma (HCC) in vitro and in vivo. This first generation of ANC was created via coupling the NO donor HL-2 and antibody targeting CD24. This novel ANC was named HN-01. HN-01 employed an antibody to accurately deliver NO to tumor sites to achieve a superior targeted affinity and therapeutic efficacy compared to NO donors alone. However, the anticancer effect of this ANC has only been determined in liver cancer. Further investigations are needed in other types of cancers [159].

The clinical benefits of NO-targeting therapies remain obscure, partially because of the insufficient clinical data. In fact, as a widely studied area for cancer therapy, there are only a limited number of clinical trials in cancers. This might be due to multiple reasons. For example, the biphasic role of NO complicates the regimen of the therapy, which makes it hard to practice in clinical settings. In addition, other novel therapies, such as immunotherapy and gene therapy, are thriving, and have shown well-established benefits and mechanisms. This further dampens people's interest in the seemingly 'problematic' NO-targeting therapies. To date, there has been only one completed phase I trial of NO-related therapy in CRC. This might be due to the successful development of the oral administration of chemotherapeutics for CRC therapy. In addition, few studies have examined the antitumor efficacy of NO delivery/controlled-releasing systems in CRC.

In addition, the clinical application of iNOS inhibitors for cancer therapy is controversial. Some studies have reported that the low level of iNOS is associated with a poor prognosis in CRC patients [160]; however, other studies have indicated a correlation between the low survival rates of patients and high level of iNOS in tumor tissues [54,161]. One study has even demonstrated that iNOS expression in tumors does not always correspond to the NO production level [162]. A clinical Phase Ib/II trial of the combinational use of NOS inhibitor L-NMMA and taxane chemotherapies is recruiting in 2020, aiming to treat refractory locally advanced or metastatic triple negative breast cancer. This trial will provide important information for the clinical application of the co-administration of NOS inhibitors with chemotherapies in cancer patients. In recent years, many natural extracts have been developed as NOS inhibitors. Although potent anticancer effects were observed in preclinical settings, none of these natural extracts have been tested in clinical trials in cancer patients. These natural products hold unique values. For example, Maqui berry itself is an edible berry, suggesting that natural extracts from it are generally considered safe. Multiple clinical trials have been performed for testing the health benefits of Maqui berry extracts. Although these trials were not conducted for cancer patients, the safety profile and PK/PD profile will be valuable for future cancer trials. However, because of the complexity of the components of these natural extracts, they are more likely to be investigated as supplements instead of cancer therapy. In addition, the beneficial effects of these natural extracts are usually achieved by targeting multiple molecules or pathways, but not specifically targeting the NO pathway.

In summary, although NO/NOS targeting therapies and NO-related drug delivery systems have shown promising results in preclinical studies, well-designed clinical studies are needed to elucidate the feasibility of this strategy in patients with CRC. There is also still an urgent need to uncover 
the hidden mechanisms of NO/NOS in CRC progression and management to facilitate the future development of more potent and less toxic therapies.

Author Contributions: Conceptualization, L.W., S.Z., and M.S.; Manuscript preparation, L.W., H.W., Z.X., and S.Z.; Manuscript editing, Y.Z.; Figure and table creation, Z.X. and Y.L. All authors have read and agreed to the published version of the manuscript.

Funding: This work was supported by the Science and Technology Planning Project of Jilin Province (no. 20200404099YY), the National Natural Science Fund of the People's Republic of China (no. 81601234 and no. 81771304), the Traditional Chinese Medicine Science and Technology Fund of Jilin Province (no.2019140), the Health Science and Technology Innovation Project of Jilin Province (no.2018ZC032 and no.20192C005), the Special Project for Health Research Talents of Jilin Province (no. 2019SCZ037), National Innovation and Entrepreneurship training Program for College Students (no. 202013706062), the Science and Technology Planning Project of Jilin Province (No. 20200201623 JC).

Conflicts of Interest: The authors declare no conflicts of interest.

\section{References}

1. Wang, L.; Cho, K.B.; Li, Y.; Tao, G.; Xie, Z.; Guo, B. Long Noncoding RNA (lncRNA)-Mediated competing endogenous rna networks provide novel potential biomarkers and therapeutic targets for colorectal cancer. Int. J. Mol. Sci. 2019, 20, 5758. [CrossRef]

2. Siegel, R.L.; Miller, K.D.; Jemal, A. Cancer statistics, 2020. Ca Cancer J. Clin. 2020, 70, 7-30. [CrossRef] [PubMed]

3. Shimokawa, M.; Ohta, Y.; Nishikori, S.; Matano, M.; Takano, A.; Fujii, M.; Date, S.; Sugimoto, S.; Kanai, T.; Sato, T. Visualization and targeting of LGR5(+) human colon cancer stem cells. Nature 2017, 545, 187-192. [CrossRef] [PubMed]

4. Yin, H.; Fang, J.; Liao, L.; Maeda, H.; Su, Q. Upregulation of heme oxygenase-1 in colorectal cancer patients with increased circulation carbon monoxide levels, potentially affects chemotherapeutic sensitivity. Bmc Cancer 2014, 14, 436. [CrossRef] [PubMed]

5. Clarke, C.N.; Kopetz, E.S. BRAF mutant colorectal cancer as a distinct subset of colorectal cancer: Clinical characteristics, clinical behavior, and response to targeted therapies. J. Gastrointest Oncol. 2015, 6, 660-667.

6. Szabo, C. Gasotransmitters in cancer: From pathophysiology to experimental therapy. Nat. Rev. Drug Discov. 2016, 15, 185-203. [CrossRef]

7. Mandal, P. Insight of nitric oxide signaling: A potential biomarker with multifaceted complex mechanism in colorectal carcinogenesis. Biochem. Biophys. Res. Commun. 2018, 495, 1766-1768. [CrossRef]

8. Huang, Z.; Fu, J.; Zhang, Y. Nitric oxide donor-based cancer therapy: Advances and prospects. J. Med. Chem. 2017, 60, 7617-7635. [CrossRef]

9. De Oliveira, G.A.; Cheng, R.Y.S.; Ridnour, L.A.; Basudhar, D.; Somasundaram, V.; McVicar, D.W.; Monteiro, H.P.; Wink, D.A. Inducible Nitric Oxide Synthase in the carcinogenesis of gastrointestinal cancers. Antioxid. Redox Signal. 2017, 26, 1059-1077. [CrossRef]

10. Rabender, C.S.; Alam, A.; Sundaresan, G.; Cardnell, R.J.; Yakovlev, V.A.; Mukhopadhyay, N.D.; Graves, P.; Zweit, J.; Mikkelsen, R.B. The Role of nitric oxide synthase uncoupling in tumor progression. Mol. Cancer. Res. 2015, 13, 1034-1043. [CrossRef]

11. Cheng, H.; Wang, L.; Mollica, M.; Re, A.T.; Wu, S.; Zuo, L. Nitric oxide in cancer metastasis. Cancer Lett. 2014, 353, 1-7. [CrossRef]

12. Salimian Rizi, B.; Achreja, A.; Nagrath, D. Nitric oxide: The forgotten child of tumor metabolism. Trends Cancer 2017, 3, 659-672. [CrossRef]

13. Pervin, S.; Singh, R.; Sen, S.; Chaudhuri, G. Dual Role of nitric oxide in cancer biology. Nitric Oxide (No) Cancer 2010, 8, 39-57.

14. Vahora, H.; Khan, M.A.; Alalami, U.; Hussain, A. The potential role of nitric oxide in halting cancer progression through chemoprevention. J. Cancer Prev. 2016, 21, 1-12. [CrossRef] [PubMed]

15. Thomas, D.D.; Ridnour, L.A.; Isenberg, J.S.; Flores-Santana, W.; Switzer, C.H.; Donzelli, S.; Hussain, P.; Vecoli, C.; Paolocci, N.; Ambs, S.; et al. The chemical biology of nitric oxide: Implications in cellular signaling. Free Radic. Biol. Med. 2008, 45, 18-31. [CrossRef] 
16. Singh, S.; Gupta, A.K. Nitric oxide: Role in tumour biology and iNOS/NO-based anticancer therapies. Cancer Chemother Pharm. 2011, 67, 1211-1224. [CrossRef] [PubMed]

17. Prueitt, R.L.; Boersma, B.J.; Howe, T.M.; Goodman, J.E.; Thomas, D.D.; Ying, L.; Pfiester, C.M.; Yfantis, H.G.; Cottrell, J.R.; Lee, D.H.; et al. Inflammation and IGF-I activate the Akt pathway in breast cancer. Int. J. Cancer 2007, 120, 796-805. [CrossRef]

18. Pervin, S.; Singh, R.; Hernandez, E.; Wu, G.; Chaudhuri, G. Nitric oxide in physiologic concentrations targets the translational machinery to increase the proliferation of human breast cancer cells: Involvement of mammalian target of rapamycin/eIF4E pathway. Cancer Res. 2007, 67, 289-299. [CrossRef]

19. Thomas, D.D.; Ridnour, L.A.; Espey, M.G.; Donzelli, S.; Ambs, S.; Hussain, S.P.; Harris, C.C.; DeGraff, W.; Roberts, D.D.; Mitchell, J.B.; et al. Superoxide fluxes limit nitric oxide-induced signaling. J. Biol. Chem. 2006, 281, 25984-25993. [CrossRef]

20. Thomas, D.D.; Espey, M.G.; Ridnour, L.A.; Hofseth, L.J.; Mancardi, D.; Harris, C.C.; Wink, D.A. Hypoxic inducible factor $1 \alpha$, extracellular signal-regulated kinase, and p53 are regulated by distinct threshold concentrations of nitric oxide. Proc. Natl. Acad. Sci. USA 2004, 101, 8894-8899. [CrossRef]

21. Isenberg, J.S.; Ridnour, L.A.; Perruccio, E.M.; Espey, M.G.; Wink, D.A.; Roberts, D.D. Thrombospondin-1 inhibits endothelial cell responses to nitric oxide in a cGMP-dependent manner. Proc. Natl. Acad. Sci. USA 2005, 102, 13141-13146. [CrossRef] [PubMed]

22. Kawasaki, K.; Smith, R.S., Jr.; Hsieh, C.M.; Sun, J.; Chao, J.; Liao, J.K. Activation of the phosphatidylinositol 3-kinase/protein kinase Akt pathway mediates nitric oxide-induced endothelial cell migration and angiogenesis. Mol. Cell. Biol. 2003, 23, 5726-5737. [CrossRef] [PubMed]

23. Olson, N.; Van Der Vliet, A. Interactions between nitric oxide and hypoxia-inducible factor signaling pathways in inflammatory disease. Nitric Oxide 2011, 25, 125-137. [CrossRef] [PubMed]

24. Hussain, S.P.; Hofseth, L.J.; Harris, C.C. Radical causes of cancer. Nat. Rev. Cancer 2003, 3, 276-285. [CrossRef] [PubMed]

25. Hussain, S.P.; Amstad, P.; Raja, K.; Ambs, S.; Nagashima, M.; Bennett, W.P.; Shields, P.G.; Ham, A.-J.; Swenberg, J.A.; Marrogi, A.J. Increased p53 mutation load in noncancerous colon tissue from ulcerative colitis: A cancer-prone chronic inflammatory disease. Cancer Res. 2000, 60, 3333-3337.

26. Rao, C.V.; Kawamori, T.; Hamid, R.; Reddy, B.S. Chemoprevention of colonic aberrant crypt foci by an inducible nitric oxide synthase-selective inhibitor. Carcinogenesis 1999, 20, 641-644. [CrossRef]

27. Ambs, S.; Merriam, W.G.; Bennett, W.P.; Felley-Bosco, E.; Ogunfusika, M.O.; Oser, S.M.; Klein, S.; Shields, P.G.; Billiar, T.R.; Harris, C.C. Frequent nitric oxide synthase-2 expression in human colon adenomas: Implication for tumor angiogenesis and colon cancer progression. Cancer Res. 1998, 58, 334-341.

28. Mandal, P. Molecular signature of nitric oxide on major cancer hallmarks of colorectal carcinoma. Inflammopharmacology 2018, 26, 331-336. [CrossRef]

29. Arias-Salvatierra, D.; Silbergeld, E.K.; Acosta-Saavedra, L.C.; Calderon-Aranda, E.S. Role of nitric oxide produced by iNOS through NF-kappaB pathway in migration of cerebellar granule neurons induced by Lipopolysaccharide. Cell Signal. 2011, 23, 425-435. [CrossRef]

30. Hickok, J.R.; Thomas, D.D. Nitric oxide and cancer therapy: The emperor has NO clothes. Curr. Pharm. Des. 2010, 16, 381-391. [CrossRef]

31. Rao, C.V. Nitric oxide signaling in colon cancer chemoprevention. Mutat. Res. 2004, 555, 107-119. [CrossRef] [PubMed]

32. Liaudet, L.; Soriano, F.G.; Szabó, C. Biology of nitric oxide signaling. Crit. Care Med. 2000, 28, N37-N52. [CrossRef] [PubMed]

33. Nathan, C.; Xie, Q.-W. Nitric oxide synthases: Roles, tolls, and controls. Cell 1994, 78, 915-918. [CrossRef]

34. Babykutty, S.; Suboj, P.; Srinivas, P.; Nair, A.S.; Chandramohan, K.; Gopala, S. Insidious role of nitric oxide in migration/invasion of colon cancer cells by upregulating MMP-2/9 via activation of cGMP-PKG-ERK signaling pathways. Clin. Exp. Metastasis 2012, 29, 471-492. [CrossRef] [PubMed]

35. Módis, K.; Coletta, C.; Chao, C.; Papapetropoulos, A.; Hellmich, M.; Szabo, C. P35 Cystathionine- $\beta$-synthase (CBS)-derived hydrogen sulfide (H2S) supports cellular bioenergetics in colon cancer cells in vitro. Nitric Oxide 2013, 31, S50. [CrossRef]

36. Alimoradi, H.; Greish, K.; Gamble, A.B.; Giles, G.I. Controlled delivery of nitric oxide for cancer therapy. Pharm. Nanotechnol. 2019, 7, 279-303. [CrossRef] 
37. Seabra, A.B.; Duran, N. Nitric oxide donors for prostate and bladder cancers: Current state and challenges. Eur. J. Pharm. 2018, 826, 158-168. [CrossRef]

38. Burke, A.J.; Sullivan, F.J.; Giles, F.J.; Glynn, S.A. The yin and yang of nitric oxide in cancer progression. Carcinogenesis 2013, 34, 503-512. [CrossRef]

39. Sonveaux, P.; Jordan, B.F.; Gallez, B.; Feron, O. Nitric oxide delivery to cancer: Why and how? Eur. J. Cancer 2009, 45, 1352-1369. [CrossRef]

40. Coulter, J.A.; McCarthy, H.O.; Xiang, J.; Roedl, W.; Wagner, E.; Robson, T.; Hirst, D.G. Nitric oxide-a novel therapeutic for cancer. Nitric Oxide 2008, 19, 192-198. [CrossRef]

41. Bonavida, B.; Khineche, S.; Huerta-Yepez, S.; Garbán, H. Therapeutic potential of nitric oxide in cancer. Drug Resist. Updates 2006, 9, 157-173. [CrossRef] [PubMed]

42. Zhu, L.; Li, L.; Zhang, Q.; Yang, X.; Zou, Z.; Hao, B.; Marincola, F.M.; Liu, Z.; Zhong, Z.; Wang, M.; et al. NOS1 S-nitrosylates PTEN and inhibits autophagy in nasopharyngeal carcinoma cells. Cell Death Discov. 2017, 3, 17011. [CrossRef] [PubMed]

43. Augsten, M.; Sjoberg, E.; Frings, O.; Vorrink, S.U.; Frijhoff, J.; Olsson, E.; Borg, A.; Ostman, A. Cancer-associated fibroblasts expressing CXCL14 rely upon NOS1-derived nitric oxide signaling for their tumor-supporting properties. Cancer Res. 2014, 74, 2999-3010. [CrossRef] [PubMed]

44. Somasundaram, V.; Basudhar, D.; Bharadwaj, G.; No, J.H.; Ridnour, L.A.; Cheng, R.Y.S.; Fujita, M.; Thomas, D.D.; Anderson, S.K.; McVicar, D.W.; et al. Molecular mechanisms of nitric oxide in cancer progression, signal transduction, and metabolism. Antioxid. Redox Signal. 2019, 30, 1124-1143. [CrossRef]

45. Vecchini, F.; Pringault, E.; Billiar, T.R.; Geller, D.A.; Hausel, P.; Felley-Bosco, E. Decreased activity of inducible nitric oxide synthase type 2 and modulation of the expression of glutathione S-transferase alpha, bcl-2, and metallothioneins during the differentiation of CaCo-2 cells. Cell Growth Differ. 1997, 8, 261-268.

46. Penarando, J.; Lopez-Sanchez, L.M.; Mena, R.; Guil-Luna, S.; Conde, F.; Hernandez, V.; Toledano, M.; Gudino, V.; Raponi, M.; Billard, C.; et al. A role for endothelial nitric oxide synthase in intestinal stem cell proliferation and mesenchymal colorectal cancer. Bmc Biol. 2018, 16, 3. [CrossRef]

47. Jess, T.; Rungoe, C.; Peyrin-Biroulet, L. Risk of colorectal cancer in patients with ulcerative colitis: A meta-analysis of population-based cohort studies. Clin. Gastroenterol. Hepatol. 2012, 10, 639-645. [CrossRef]

48. Vannini, F.; Kashfi, K.; Nath, N. The dual role of iNOS in cancer. Redox Biol. 2015, 6, 334-343. [CrossRef]

49. Kolios, G.; Valatas, V.; Ward, S.G. Nitric oxide in inflammatory bowel disease: A universal messenger in an unsolved puzzle. Immunology 2004, 113, 427-437. [CrossRef]

50. Erdman, S.; Rao, V.; Poutahidis, T.; Rogers, A.; Taylor, C.; Jackson, E.; Ge, Z.; Lee, C.; Schauer, D.; Wogan, G. Nitric oxide and TNF- $\alpha$ trigger colonic inflammation and carcinogenesis in Helicobacter hepaticus-infected, Rag2-deficient mice. Proc. Natl. Acad. Sci. USA 2009, 106, 1027-1032. [CrossRef]

51. Zhang, R.; Ma, A.; Urbanski, S.J.; McCafferty, D.-M. Induction of inducible nitric oxide synthase: A protective mechanism in colitis-induced adenocarcinoma. Carcinogenesis 2007, 28, 1122-1130. [CrossRef] [PubMed]

52. Hao, X.P.; Pretlow, T.G.; Rao, J.S.; Pretlow, T.P. Inducible nitric oxide synthase (iNOS) is expressed similarly in multiple aberrant crypt foci and colorectal tumors from the same patients. Cancer Res. 2001, 61, 419-422.

53. McCafferty, D.-M.; Sihota, E.; Muscara, M.; Wallace, J.L.; Sharkey, K.A.; Kubes, P. Spontaneously developing chronic colitis in IL-10/iNOS double-deficient mice. Am. J. Physiol. Gastrointest. Liver Physiol. 2000, 279, G90-G99. [CrossRef] [PubMed]

54. Gochman, E.; Mahajna, J.; Shenzer, P.; Dahan, A.; Blatt, A.; Elyakim, R.; Reznick, A.Z. The expression of iNOS and nitrotyrosine in colitis and colon cancer in humans. Acta Histochem. 2012, 114, 827-835. [CrossRef]

55. Sun, M.-H.; Han, X.-C.; Jia, M.-K.; Jiang, W.-D.; Wang, M.; Zhang, H.; Han, G.; Jiang, Y. Expressions of inducible nitric oxide synthase and matrix metalloproteinase- 9 and their effects on angiogenesis and progression of hepatocellular carcinoma. World J. Gastroenterol. Wjg 2005, 11, 5931. [CrossRef]

56. Cianchi, F.; Cortesini, C.; Fantappiè, O.; Messerini, L.; Sardi, I.; Lasagna, N.; Perna, F.; Fabbroni, V.; Di Felice, A.; Perigli, G. Cyclooxygenase-2 activation mediates the proangiogenic effect of nitric oxide in colorectal cancer. Clin. Cancer Res. 2004, 10, 2694-2704. [CrossRef] [PubMed]

57. Lim, K.H.; Ancrile, B.B.; Kashatus, D.F.; Counter, C.M. Tumour maintenance is mediated by eNOS. Nature 2008, 452, 646-649. [CrossRef] [PubMed]

58. Fukumura, D.; Kashiwagi, S.; Jain, R.K. The role of nitric oxide in tumour progression. Nat. Rev. Cancer 2006, 6, 521-534. [CrossRef] 
59. Jadeski, L.C.; Hum, K.O.; Chakraborty, C.; Lala, P.K. Nitric oxide promotes murine mammary tumour growth and metastasis by stimulating tumour cell migration, invasiveness and angiogenesis. Int. J. Cancer 2000, 86, 30-39. [CrossRef]

60. Takahashi, M.; Fukuda, K.; Ohata, T.; Sugimura, T.; Wakabayashi, K. Increased expression of inducible and endothelial constitutive nitric oxide synthases in rat colon tumors induced by azoxymethane. Cancer Res. 1997, 57, 1233-1237.

61. Yu, S.; Jia, L.; Zhang, Y.; Wu, D.; Xu, Z.; Ng, C.F.; To, K.K.; Huang, Y.; Chan, F.L. Increased expression of activated endothelial nitric oxide synthase contributes to antiandrogen resistance in prostate cancer cells by suppressing androgen receptor transactivation. Cancer Lett. 2013, 328, 83-94. [CrossRef] [PubMed]

62. Ying, L.; Hofseth, L.J. An emerging role for endothelial nitric oxide synthase in chronic inflammation and cancer. Cancer Res. 2007, 67, 1407-1410. [CrossRef] [PubMed]

63. Wang, L.; Shi, G.G.; Yao, J.C.; Gong, W.; Wei, D.; Wu, T.T.; Ajani, J.A.; Huang, S.; Xie, K. Expression of endothelial nitric oxide synthase correlates with the angiogenic phenotype of and predicts poor prognosis in human gastric cancer. Gastric Cancer 2005, 8, 18-28. [CrossRef] [PubMed]

64. Gao, Y.; Zhou, S.; Xu, Y.; Sheng, S.; Qian, S.Y.; Huo, X. Nitric oxide synthase inhibitors $1400 W$ and L-NIO inhibit angiogenesis pathway of colorectal cancer. Nitric Oxide 2019, 83, 33-39. [CrossRef]

65. Thomsen, L.L.; Scott, J.M.; Topley, P.; Knowles, R.G.; Keerie, A.-J.; Frend, A.J. Selective inhibition of inducible nitric oxide synthase inhibits tumor growth in vivo: Studies with 1400W, a novel inhibitor. Cancer Res. 1997, 57, 3300-3304. [PubMed]

66. Gao, Y.; Zhou, S.; Pang, L.; Yang, J.; Li, H.J.; Huo, X.; Qian, S.Y. Celastrol suppresses nitric oxide synthases and the angiogenesis pathway in colorectal cancer. Free Radic. Res. 2019, 53, 324-334. [CrossRef] [PubMed]

67. Céspedes-Acuña, C.L.; Xiao, J.; Wei, Z.-J.; Chen, L.; Bastias, J.M.; Avila, J.G.; Alarcon-Enos, J.; Werner-Navarrete, E.; Kubo, I. Antioxidant and anti-inflammatory effects of extracts from Maqui berry Aristotelia chilensis in human colon cancer cells. J. Berry Res. 2018, 8, 275-296. [CrossRef]

68. Deepa, M.; Sureshkumar, T.; Satheeshkumar, P.K.; Priya, S. Antioxidant rich Morus alba leaf extract induces apoptosis in human colon and breast cancer cells by the downregulation of nitric oxide produced by inducible nitric oxide synthase. Nutr. Cancer 2013, 65, 305-310. [CrossRef]

69. Wu, X.; Song, M.; Gao, Z.; Sun, Y.; Wang, M.; Li, F.; Zheng, J.; Xiao, H. Nobiletin and its colonic metabolites suppress colitis-associated colon carcinogenesis by down-regulating iNOS, inducing antioxidative enzymes and arresting cell cycle progression. J. Nutr. Biochem. 2017, 42, 17-25. [CrossRef]

70. Rafa, H.; Benkhelifa, S.; AitYounes, S.; Saoula, H.; Belhadef, S.; Belkhelfa, M.; Boukercha, A.; Toumi, R.; Soufli, I.; Morales, O.; et al. All-Trans retinoic acid modulates TLR4/NF-kappaB signaling pathway targeting TNF-alpha and nitric oxide synthase 2 expression in colonic mucosa during ulcerative colitis and colitis associated cancer. Mediat. Inflamm. 2017, 2017, 7353252. [CrossRef]

71. Kong, Z.-L.; Kao, N.-J.; Hu, J.-Y.; Wu, C.-S. Fucoxanthin-rich brown algae extract decreases inflammation and attenuates colitis-associated colon cancer in mice. J. Food Nutr. Res 2016, 4, 137-147.

72. Heo, S.-J.; Yoon, W.-J.; Kim, K.-N.; Oh, C.; Choi, Y.-U.; Yoon, K.-T.; Kang, D.-H.; Qian, Z.-J.; Choi, I.-W.; Jung, W.-K. Anti-inflammatory effect of fucoxanthin derivatives isolated from Sargassum siliquastrum in lipopolysaccharide-stimulated RAW 264.7 macrophage. Food Chem. Toxicol. 2012, 50, 3336-3342. [CrossRef] [PubMed]

73. Narayanan, B.A.; Narayanan, N.K.; Desai, D.; Pittman, B.; Reddy, B.S. Effects of a combination of docosahexaenoic acid and 1, 4-phenylene bis (methylene) selenocyanate on cyclooxygenase 2, inducible nitric oxide synthase and $\beta$-catenin pathways in colon cancer cells. Carcinogenesis 2004, 25, 2443-2449. [CrossRef] [PubMed]

74. Narayanan, B.A.; Narayanan, N.K.; Simi, B.; Reddy, B.S. Modulation of inducible nitric oxide synthase and related proinflammatory genes by the omega-3 fatty acid docosahexaenoic acid in human colon cancer cells. Cancer Res. 2003, 63, 972-979.

75. Umesalma, S.; Sudhandiran, G. Differential inhibitory effects of the polyphenol ellagic acid on inflammatory mediators NF- $\mathrm{kB}$, iNOS, COX-2, TNF- $\alpha$, and IL-6 in 1, 2-dimethylhydrazine-induced rat colon carcinogenesis. Basic Clin. Pharmacol. Toxicol. 2010, 107, 650-655. [CrossRef] [PubMed]

76. Harmen, F.; Hanifah, R.S.; Novitarani, N.A.; Tedjo, A.; Azizah, N.N.; Putrianingsih, R.; Fachri, W.; Kusmardi, K. The Inhibition of Ethanol Extract of Phaleria macrocarpa Stem Bark on iNOS Expression of HCT116 Colorectal Cancer Cell Line. J. Pharm. Sci. Res. 2019, 11, 892-895. 
77. Jeong, S.; Kim, B.G.; Kim, D.Y.; Kim, B.R.; Kim, J.L.; Park, S.H.; Na, Y.J.; Jo, M.J.; Yun, H.K.; Jeong, Y.A. Cannabidiol overcomes oxaliplatin resistance by enhancing NOS3-and SOD2-induced autophagy in human colorectal cancer cells. Cancers 2019, 11, 781. [CrossRef]

78. Benkhelifa, S.; Rafa, H.; Belhadef, S.; Ait-Kaci, H.; Medjeber, O.; Belkhelfa, M.; Hetit, S.; Ait-Younes, S.; Moralès, O.; Mahfouf, H. Aberrant up-regulation of iNOS/NO system is correlated with an increased abundance of Foxp3+ cells and reduced effector/memory cell markers expression during colorectal cancer: Immunomodulatory effects of cetuximab combined with chemotherapy. Inflammopharmacology 2019, 27, 685-700. [CrossRef]

79. Ding, Q.-G.; Zang, J.; Gao, S.; Gao, Q.; Duan, W.; Li, X.; Xu, W.; Zhang, Y. Nitric oxide donor hybrid compounds as promising anticancer agents. Drug Discov. 2016, 10, 276-284. [CrossRef]

80. Stevens, E.V.; Carpenter, A.W.; Shin, J.H.; Liu, J.; Der, C.J.; Schoenfisch, M.H. Nitric oxide-releasing silica nanoparticle inhibition of ovarian cancer cell growth. Mol. Pharm. 2010, 7, 775-785. [CrossRef]

81. Fang, L.; Lehmann, J. NO donor hybrid compounds as multifunctional therapeutic agents. Expert Opin. Ther. Pat. 2008, 18, 1111-1125. [CrossRef]

82. Dunlap, T.; Abdul-Hay, S.O.; Chandrasena, R.E.P.; Hagos, G.K.; Sinha, V.; Wang, Z.; Wang, H.; Thatcher, G.R. Nitrates and NO-NSAIDs in cancer chemoprevention and therapy: In vitro evidence querying the NO donor functionality. Nitric Oxide 2008, 19, 115-124. [CrossRef] [PubMed]

83. Scatena, R.; Bottoni, P.; Martorana, G.E.; Giardina, B. Nitric oxide donor drugs: An update on pathophysiology and therapeutic potential. Expert Opin. Investig. Drugs 2005, 14, 835-846. [CrossRef] [PubMed]

84. Tashjian, A.H., Jr.; Voelkel, E.F.; Goldhaber, P.; Levine, L. Successful treatment of hypercalcemia by indomethacin in mice bearing a prostaglandin-producing fibrosarcoma. Prostaglandins 1973, 3, 515-524. [CrossRef]

85. Din, F.V.; Theodoratou, E.; Farrington, S.M.; Tenesa, A.; Barnetson, R.A.; Cetnarskyj, R.; Stark, L.; Porteous, M.E.; Campbell, H.; Dunlop, M.G. Effect of aspirin and NSAIDs on risk and survival from colorectal cancer. Gut 2010, 59, 1670-1679. [CrossRef]

86. Slattery, M.L.; Samowitz, W.; Hoffman, M.; Ma, K.N.; Levin, T.R.; Neuhausen, S. Aspirin, NSAIDs, and colorectal cancer: Possible involvement in an insulin-related pathway. Cancer Epidemiol. Prev. Biomark. 2004, 13, 538-545.

87. Rayyan, Y.; Williams, J.; Rigas, B. The role of NSAIDs in the prevention of colon cancer. Cancer Investig. 2002, 20, 1002-1011. [CrossRef]

88. Gupta, R.A.; DuBois, R.N. Aspirin, NSAIDS, and Colon Cancer Prevention: Mechanisms? Elsevier: Amsterdam, The Netherlands, 1998.

89. Ahnen, D.J. Colon cancer prevention by NSAIDs: What is the mechanism of action? Eur. J. Surg. 1998, 164, 111-114. [CrossRef]

90. Thun, M.J. NSAID use and decreased risk of gastrointestinal cancers. Gastroenterol. Clin. North Am. 1996, 25, 333-348. [CrossRef]

91. Waddell, W.R.; Gerner, R.E. Indomethacin and ascorbate inhibit desmoid tumors. J. Surg. Oncol. 1980, 15, 85-90. [CrossRef]

92. Lynch, P.M.; Burke, C.A.; Phillips, R.; Morris, J.S.; Slack, R.; Wang, X.; Liu, J.; Patterson, S.; Sinicrope, F.A.; Rodriguez-Bigas, M.A. An international randomised trial of celecoxib versus celecoxib plus difluoromethylornithine in patients with familial adenomatous polyposis. Gut 2016, 65, 286-295. [CrossRef] [PubMed]

93. Food Drug Administration. Pfizer, Inc; withdrawal of approval of familial adenomatous polyposis indication for CELEBREX. Federal Register. 2012; Volume 77. Available online: https://www.govinfo.gov/content/pkg/ FR-2012-06-08/html/2012-13900.htm (accessed on 20 May 2020).

94. Rigas, B.; Kashfi, K. Nitric-oxide-donating NSAIDs as agents for cancer prevention. Trends Mol. Med. 2004, 10, 324-330. [CrossRef] [PubMed]

95. Williams, J.L.; Borgo, S.; Hasan, I.; Castillo, E.; Traganos, F.; Rigas, B. Nitric oxide-releasing nonsteroidal anti-inflammatory drugs (NSAIDs) alter the kinetics of human colon cancer cell lines more effectively than traditional NSAIDs: Implications for colon cancer chemoprevention. Cancer Res. 2001, 61, 3285-3289. [PubMed] 
96. Fiorucci, S.; Santucci, L.; Gresele, P.; Faccino, R.M.; Del Soldato, P.; Morelli, A. Gastrointestinal safety of NO-aspirin (NCX-4016) in healthy human volunteers: A proof of concept endoscopic study. Gastroenterology 2003, 124, 600-607. [CrossRef] [PubMed]

97. Bak, A.W.; McKnight, W.; Li, P.; Del Soldato, P.; Calignano, A.; Cirino, G.; Wallace, J.L. Cyclooxygenase-independent chemoprevention with an aspirin derivative in a rat model of colonic adenocarcinoma. Life Sci. 1998, 62, 367-373. [CrossRef]

98. Chattopadhyay, M.; Kodela, R.; Olson, K.R.; Kashfi, K. NOSH-aspirin (NBS-1120), a novel nitric oxide-and hydrogen sulfide-releasing hybrid is a potent inhibitor of colon cancer cell growth in vitro and in a xenograft mouse model. Biochem. Biophys. Res. Commun. 2012, 419, 523-528. [CrossRef]

99. Kashfi, K.; Chattopadhyay, M.; Kodela, R. NOSH-sulindac (AVT-18A) is a novel nitric oxide-and hydrogen sulfide-releasing hybrid that is gastrointestinal safe and has potent anti-inflammatory, analgesic, antipyretic, anti-platelet, and anti-cancer properties. Redox Biol. 2015, 6, 287-296. [CrossRef]

100. Chegaev, K.; Riganti, C.; Lazzarato, L.; Rolando, B.; Guglielmo, S.; Campia, I.; Fruttero, R.; Bosia, A.; Gasco, A. Nitric oxide donor doxorubicins accumulate into doxorubicin-resistant human colon cancer cells inducing cytotoxicity. Acs Med. Chem. Lett. 2011, 2, 494-497. [CrossRef]

101. Ai, Y.; Kang, F.; Huang, Z.; Xue, X.; Lai, Y.; Peng, S.; Tian, J.; Zhang, Y. Synthesis of CDDO-amino acid-nitric oxide donor trihybrids as potential antitumor agents against both drug-sensitive and drug-resistant colon cancer. J. Med. Chem. 2015, 58, 2452-2464. [CrossRef]

102. Millet, A.; Bettaieb, A.; Renaud, F.; Prevotat, L.; Hammann, A.; Solary, E.; Mignotte, B.; Jeannin, J.F. Influence of the nitric oxide donor glyceryl trinitrate on apoptotic pathways in human colon cancer cells. Gastroenterology 2002, 123, 235-246. [CrossRef]

103. Pathi, S.S.; Jutooru, I.; Chadalapaka, G.; Sreevalsan, S.; Anand, S.; Thatcher, G.R.; Safe, S. GT-094, a NO-NSAID, inhibits colon cancer cell growth by activation of a reactive oxygen species-microRNA-27a: ZBTB10-specificity protein pathway. Mol. Cancer Res. 2011, 9, 195-202. [CrossRef] [PubMed]

104. Williams, J.L.; Ji, P.; Ouyang, N.; Kopelovich, L.; Rigas, B. Protein nitration and nitrosylation by NO-donating aspirin in colon cancer cells: Relevance to its mechanism of action. Exp. Cell Res. 2011, 317, 1359-1367. [CrossRef] [PubMed]

105. Hua, A.; Mackenzie, G.G.; Rigas, B. The differential cell signaling effects of two positional isomers of the anticancer NO-donating aspirin. Int. J. Oncol. 2009, 35, 837-844. [PubMed]

106. Rigas, B. Novel agents for cancer prevention based on nitric oxide. Biochem. Soc. Trans. 2007, 35, $1364-1368$. [CrossRef] [PubMed]

107. Kashfi, K.; Rigas, B. The mechanism of action of nitric oxide-donating aspirin. Biochem. Biophys. Res. Commun. 2007, 358, 1096-1101. [CrossRef] [PubMed]

108. Ouyang, N.; Williams, J.L.; Tsioulias, G.J.; Gao, J.; Iatropoulos, M.J.; Kopelovich, L.; Kashfi, K.; Rigas, B. Nitric oxide-donating aspirin prevents pancreatic cancer in a hamster tumor model. Cancer Res. 2006, 66, 4503-4511. [CrossRef]

109. Kashfi, K.; Rigas, B. Molecular targets of nitric-oxide-donating aspirin in cancer. Biochem. Soc. Trans. 2005, 33, 701-704. [CrossRef]

110. Karateev, A.; Nasonov, E.; Yakhno, N.; Ivashkin, V.; Chichasova, N.; Alekseeva, L.; Karpov, Y.A.; Evseev, M.; Kukushkin, M.; Danilov, A. Clinical guidelines «Rational use of nonsteroidal anti-inflammatory drugs (NSAIDs) in clinical practice». Mod. Rheumatol. J. 2015, 9, 4-23. [CrossRef]

111. Day, R.O.; Graham, G.G. Non-steroidal anti-inflammatory drugs (NSAIDs). Bmj 2013, 346, f3195.

112. Mallen, S.R.; Essex, M.N.; Zhang, R. Gastrointestinal tolerability of NSAIDs in elderly patients: A pooled analysis of 21 randomized clinical trials with celecoxib and nonselective NSAIDs. Curr. Med Res. Opin. 2011, 27, 1359-1366. [CrossRef]

113. Patrono, C.; Baigent, C. Low-dose aspirin, coxibs, and other NSAIDS: A clinical mosaic emerges. Mol. Interv. 2009, 9, 31. [CrossRef] [PubMed]

114. Moore, R.A.; Derry, S.; Phillips, C.J.; McQuay, H.J. Nonsteroidal anti-inflammatory drugs (NSAIDs), cyxlooxygenase-2 selective inhibitors (coxibs) and gastrointestinal harm: Review of clinical trials and clinical practice. Bmc Musculoskelet. Disord. 2006, 7, 79. [CrossRef]

115. Fiorucci, S.; Antonelli, E. NO-NSAIDs: From inflammatory mediators to clinical readouts. Inflamm. Allergy-Drug Targets (Former. Curr. Drug Targets-Inflamm. Allergy) 2006, 5, 121-131. [CrossRef] [PubMed] 
116. Bergh, M.S.; Budsberg, S.C. The coxib NSAIDs: Potential clinical and pharmacologic importance in veterinary medicine. J. Vet. Intern. Med. 2005, 19, 633-643. [CrossRef] [PubMed]

117. Tarnawski, A.S.; Jones, M.K. Inhibition of angiogenesis by NSAIDs: Molecular mechanisms and clinical implications. J. Mol. Med. 2003, 81, 627-636. [CrossRef] [PubMed]

118. Mukherjee, A.; Hale, V.; Borga, O.; Stein, R. Predictability of the clinical potency of NSAIDs from the preclinical pharmacodynamics in rats. Inflamm. Res. 1996, 45, 531-540. [CrossRef] [PubMed]

119. Brater, D.C. Clinical pharmacology of NSAIDs. J. Clin. Pharmacol. 1988, 28, 518-523. [CrossRef]

120. Roujeau, J.-C. Clinical aspects of skin reactions to NSAIDs. Scand. J. Rheumatol. 1987, 16, 131-134. [CrossRef]

121. Verbeeck, R.K.; Blackburn, J.L.; Loewen, G.R. Clinical pharmacokinetics of non-steroidal anti-inflammatory drugs. Clin. Pharmacokinet. 1983, 8, 297-331. [CrossRef]

122. Yeh, R.K.; Chen, J.; Williams, J.L.; Baluch, M.; Hundley, T.R.; Rosenbaum, R.E.; Kalala, S.; Traganos, F.; Benardini, F.; Del Soldato, P. NO-donating nonsteroidal antiinflammatory drugs (NSAIDs) inhibit colon cancer cell growth more potently than traditional NSAIDs: A general pharmacological property? Biochem. Pharmacol. 2004, 67, 2197-2205. [CrossRef]

123. Gao, J.; Liu, X.; Rigas, B. Nitric oxide-donating aspirin induces apoptosis in human colon cancer cells through induction of oxidative stress. Proc. Natl. Acad. Sci. USA 2005, 102, 17207-17212. [CrossRef] [PubMed]

124. Nath, N.; Kashfi, K.; Chen, J.; Rigas, B. Nitric oxide-donating aspirin inhibits $\beta$-catenin/T cell factor (TCF) signaling in SW480 colon cancer cells by disrupting the nuclear $\beta$-catenin-TCF association. Proc. Natl. Acad. Sci. USA 2003, 100, 12584-12589. [CrossRef] [PubMed]

125. Williams, J.L.; Ji, P.; Ouyang, N.; Liu, X.; Rigas, B. NO-donating aspirin inhibits the activation of NF- $k B$ in human cancer cell lines and Min mice. Carcinogenesis 2008, 29, 390-397. [CrossRef] [PubMed]

126. Williams, J.L.; Nath, N.; Chen, J.; Hundley, T.R.; Gao, J.; Kopelovich, L.; Kashfi, K.; Rigas, B. Growth inhibition of human colon cancer cells by nitric oxide (NO)-donating aspirin is associated with cyclooxygenase-2 induction and $\beta$-catenin/T-cell factor signaling, nuclear factor- $\mathrm{kB}$, and NO synthase 2 inhibition: Implications for chemoprevention. Cancer Res. 2003, 63, 7613-7618. [PubMed]

127. Rao, C.V.; Reddy, B.S.; Steele, V.E.; Wang, C.; Liu, X.; Ouyang, N.; Patlolla, J.M.; Simi, B.; Kopelovich, L.; Rigas, B. Nitric oxide-releasing aspirin and indomethacin are potent inhibitors against colon cancer in azoxymethane-treated rats: Effects on molecular targets. Mol. Cancer Ther. 2006, 5, 1530-1538. [CrossRef]

128. Fonseca, M.D.; Cunha, F.Q.; Kashfi, K.; Cunha, T.M. NOSH-aspirin (NBS-1120), a dual nitric oxide and hydrogen sulfide-releasing hybrid, reduces inflammatory pain. Pharmacol. Res. Perspect. 2015, 3. [CrossRef]

129. Matsumura, Y.; Maeda, H. A new concept for macromolecular therapeutics in cancer chemotherapy: Mechanism of tumoritropic accumulation of proteins and the antitumor agent smancs. Cancer Res 1986, 46, 6387-6392.

130. Maeda, H.; Wu, J.; Sawa, T.; Matsumura, Y.; Hori, K. Tumor vascular permeability and the EPR effect in macromolecular therapeutics: A review. J. Control. Release 2000, 65, 271-284. [CrossRef]

131. Maeda, H. Toward a full understanding of the EPR effect in primary and metastatic tumors as well as issues related to its heterogeneity. Adv Drug Deliv Rev 2015, 91, 3-6. [CrossRef] [PubMed]

132. Maeda, H.; Noguchi, Y.; Sato, K.; Akaike, T. Enhanced vascular permeability in solid tumor is mediated by nitric oxide and inhibited by both new nitric oxide scavenger and nitric oxide synthase inhibitor. Jpn. J. Cancer Res. 1994, 85, 331-334. [CrossRef]

133. Wu, J.; Akaike, T.; Maeda, H. Modulation of enhanced vascular permeability in tumors by a bradykinin antagonist, a cyclooxygenase inhibitor, and a nitric oxide scavenger. Cancer Res. 1998, 58, 159-165. [PubMed]

134. Tanaka, S.; Akaike, T.; Wu, J.; Fang, J.; Sawa, T.; Ogawa, M.; Beppu, T.; Maeda, H. Modulation of tumor-selective vascular blood flow and extravasation by the stable prostaglandin $\mathrm{I} 2$ analogue beraprost sodium. J. Drug Target. 2003, 11, 45-52. [CrossRef] [PubMed]

135. Xie, Z.; Shen, Q.; Xie, C.; Lu, W.; Peng, C.; Wei, X.; Li, X.; Su, B.; Gao, C.; Liu, M. Retro-inverso bradykinin opens the door of blood-brain tumor barrier for nanocarriers in glioma treatment. Cancer Lett. 2015, 369, 144-151. [CrossRef] [PubMed]

136. Su, B.; Wang, R.; Xie, Z.; Ruan, H.; Li, J.; Xie, C.; Lu, W.; Wang, J.; Wang, D.; Liu, M. Effect of Retro-Inverso Isomer of Bradykinin on Size-Dependent Penetration of Blood-Brain Tumor Barrier. Small 2018, 14, 1702331. [CrossRef]

137. Sessa, W. Molecular control of blood flow and angiogenesis: Role of nitric oxide. J. Thromb. Haemost. 2009, 7, 35-37. [CrossRef] [PubMed] 
138. Islam, W.; Fang, J.; Imamura, T.; Etrych, T.; Subr, V.; Ulbrich, K.; Maeda, H. Augmentation of the Enhanced Permeability and Retention Effect with Nitric Oxide-Generating Agents Improves the Therapeutic Effects of Nanomedicines. Mol. Cancer 2018, 17, 2643-2653. [CrossRef]

139. Fang, J.; Liao, L.; Yin, H.; Nakamura, H.; Shin, T.; Maeda, H. Enhanced bacterial tumor delivery by modulating the EPR effect and therapeutic potential of Lactobacillus casei. J. Pharm. Sci. 2014, 103, 3235-3243. [CrossRef]

140. Scatena, R.; Bottoni, P.; Pontoglio, A.; Giardina, B. Pharmacological modulation of nitric oxide release: New pharmacological perspectives, potential benefits and risks. Curr. Med. Chem. 2010, 17, 61-73. [CrossRef]

141. Belinsky, M.; Jaiswal, A.K. NAD (P) H: Quinone oxidoreductase 1 (DT-diaphorase) expression in normal and tumor tissues. Cancer Metastasis Rev. 1993, 12, 103-117. [CrossRef]

142. Luo, X.; Wu, J.; Lv, T.; Lai, Y.; Zhang, H.; Lu, J.-J.; Zhang, Y.; Huang, Z. Synthesis and evaluation of novel O2-derived diazeniumdiolates as photochemical and real-time monitoring nitric oxide delivery agents. Org. Chem. Front. 2017, 4, 2445-2449. [CrossRef]

143. Hasegawa, U.; Wang, T.; Chen, J.J.; Uyama, H.; Van Der Vlies, A.J. Furoxan-Bearing Micelles for Nitric Oxide Delivery. Macromol Biosci 2016, 16, 1009-1018. [CrossRef] [PubMed]

144. Stamler, J.S.; Jaraki, O.; Osborne, J.; Simon, D.I.; Keaney, J.; Vita, J.; Singel, D.; Valeri, C.R.; Loscalzo, J. Nitric oxide circulates in mammalian plasma primarily as an S-nitroso adduct of serum albumin. Proc. Natl. Acad. Sci. USA 1992, 89, 7674-7677. [CrossRef]

145. Katayama, N.; Nakajou, K.; Komori, H.; Uchida, K.; Yokoe, J.-i.; Yasui, N.; Yamamoto, H.; Kai, T.; Sato, M.; Nakagawa, T. Design and evaluation of S-nitrosylated human serum albumin as a novel anticancer drug. J. Pharmacol. Exp. Ther. 2008, 325, 69-76. [CrossRef] [PubMed]

146. Ishima, Y.; Fang, J.; Kragh-Hansen, U.; Yin, H.; Liao, L.; Katayama, N.; Watanabe, H.; Kai, T.; Suenaga, A.; Maeda, H.; et al. Tuning of poly-S-nitrosated human serum albumin as superior antitumor nanomedicine. J. Pharm. Sci. 2014, 103, 2184-2188. [CrossRef] [PubMed]

147. Kinoshita, R.; Ishima, Y.; Ikeda, M.; Kragh-Hansen, U.; Fang, J.; Nakamura, H.; Chuang, V.T.; Tanaka, R.; Maeda, H.; Kodama, A.; et al. S-Nitrosated human serum albumin dimer as novel nano-EPR enhancer applied to macromolecular anti-tumor drugs such as micelles and liposomes. J. Control Release 2015, 217, 1-9. [CrossRef] [PubMed]

148. Kinoshita, R.; Ishima, Y.; Chuang, V.T.G.; Nakamura, H.; Fang, J.; Watanabe, H.; Shimizu, T.; Okuhira, K.; Ishida, T.; Maeda, H.; et al. Improved anticancer effects of albumin-bound paclitaxel nanoparticle via augmentation of EPR effect and albumin-protein interactions using S-nitrosated human serum albumin dimer. Biomaterials 2017, 140, 162-169. [CrossRef] [PubMed]

149. Qin, L.; Gao, H. The application of nitric oxide delivery in nanoparticle-based tumor targeting drug delivery and treatment. Asian J Pharm Sci 2019, 14, 380-390. [CrossRef]

150. Wang, Y.; Yang, T.; He, Q. Strategies for engineering advanced nanomedicines for gas therapy of cancer. Natl. Sci. Rev. 2020. [CrossRef]

151. Seabra, A. Nitric Oxide Donors: Novel Biomedical Applications and Perspectives; Academic Press: London, UK, 2017.

152. Sukhatme, V.; Bouche, G.; Meheus, L.; Sukhatme, V.P.; Pantziarka, P. Repurposing Drugs in Oncology (ReDO)—Nitroglycerin as an anti-cancer agent. Ecancermedicalscience 2015, 9. [CrossRef]

153. Yasuda, H.; Yamaya, M.; Nakayama, K.; Sasaki, T.; Ebihara, S.; Kanda, A.; Asada, M.; Inoue, D.; Suzuki, T.; Okazaki, T. Randomized phase II trial comparing nitroglycerin plus vinorelbine and cisplatin with vinorelbine and cisplatin alone in previously untreated stage IIIB/IV non-small-cell lung cancer. J. Clin. Oncol. 2006, 24, 688-694. [CrossRef]

154. Burn, J.; Sheth, H.; Elliott, F.; Reed, L.; Macrae, F.; Mecklin, J.-P.; Möslein, G.; McRonald, F.E.; Bertario, L.; Evans, D.G. Cancer prevention with aspirin in hereditary colorectal cancer (Lynch syndrome), 10-year follow-up and registry-based 20-year data in the CAPP2 study: A double-blind, randomised, placebo-controlled trial. Lancet 2020, 395, 1855-1863. [CrossRef]

155. Tikk, K.; Czock, D.; Haefeli, W.E.; Kopp-Schneider, A.; Brenner, H. Clinical trial protocol of the ASTER trial: A double-blind, randomized, placebo-controlled phase III trial evaluating the use of acetylsalicylic acid (ASA) for enhanced early detection of colorectal neoplasms. Bmc Cancer 2018, 18, 1-9. [CrossRef] [PubMed]

156. Ján, P.; Roman, H.; Ondřej, B.; Štěpán, T.; Jiří, N.; Eva, M.; Bořivoj, V. Acetylsalicylic Acid and its Potential for Chemoprevention of Colorectal Carcinoma. Klin. Onkol. 2018, 31, 77-81. 
157. Félétou, M. Discovery of Nitric Oxide and Translation to Clinical Application. Physiol. (BethesdaMd.) 2016, 31, 76-77. [CrossRef]

158. Hays, E.; Bonavida, B. Nitric oxide-mediated enhancement and reversal of resistance of anticancer therapies. Antioxidants 2019, 8, 407. [CrossRef]

159. Rigas, B.; Williams, J.L. NO-releasing NSAIDs and colon cancer chemoprevention: A promising novel approach. Int. J. Oncol. 2002, 20, 885-890. [CrossRef]

160. Ohta, T.; Takahashi, M.; Ochiai, A. Increased protein expression of both inducible nitric oxide synthase and cyclooxygenase-2 in human colon cancers. Cancer Lett. 2006, 239, 246-253. [CrossRef]

161. Holotiuk, V.; Kryzhanivska, A.; Churpiy, I.; Tataryn, B.; Ivasiutyn, D.Y. Role of nitric oxide in pathogenesis of tumor growth and its possible application in cancer treatment. Exp. Oncol. 2019, 41, 210-215. [CrossRef]

162. Rahat, M.A.; Hemmerlein, B. Macrophage-tumor cell interactions regulate the function of nitric oxide. Front. Physiol. 2013, 4, 144. [CrossRef]

(C) 2020 by the authors. Licensee MDPI, Basel, Switzerland. This article is an open access article distributed under the terms and conditions of the Creative Commons Attribution (CC BY) license (http://creativecommons.org/licenses/by/4.0/). 